\title{
Spatial analysis of logistics ecological efficiency and its influencing factors in China: based on Super- SBM-Undesirable and spatial Dubin models
}

Dongling Bai ( $\sim$ bdl990@chd.edu.cn )

Chang'an University https://orcid.org/0000-0002-2644-6903

Qianli Dong ( $\nabla$ dongql@chd.edu.cn )

Chang'an University

Syed Abdul Rehman Khan

Tsinghua University

Yan Chen

Chang'an University

Dongfang Wang

Wuyi University

Lei Yang

Chang'an University

\section{Research Article}

Keywords: Logistics ecological efficiency, Air pollutants, Spatial information association, Spatial directionality, Spatial autocorrelation, Super-SBM-Undesirable, Spatial Dubin model

Posted Date: June 14th, 2021

DOl: https://doi.org/10.21203/rs.3.rs-613381/v1

License: (9) This work is licensed under a Creative Commons Attribution 4.0 International License.

Read Full License

Version of Record: A version of this preprint was published at Environmental Science and Pollution Research on September 12th, 2021. See the published version at https://doi.org/10.1007/s11356-02116323-x. 
Title:

Spatial analysis of logistics ecological efficiency and its influencing factors in China:

\section{based on Super-SBM-Undesirable and spatial Dubin models}

Dongling Bai ${ }^{1,2} \cdot$ Qianli Dong ${ }^{1} \cdot$ Syed Abdul Rehman Khan ${ }^{3} \cdot$ Yan Chen $^{1} \cdot$ Dongfang Wang $^{4} \cdot$ Lei Yang $^{5}$

Dongling Bai

bd1990@chd.edu.cn

Corresponding author

Qianli Dong

dongq1@chd.edu.cn

+86-029-82334335

Chang'an university Middle-section of Nan'er Huan Road Xi'an, Shaanxi Province, 710064, China

1. School of Economics and Management, Chang'an University, Xi' an Shaaxi 710064, China

2. School of Management Engineering, Zhengzhou University of Aeronautics, Zhengzhou Henan 450046, China

3. School of Economics and Management, Tsinghua University, Beijing 100084, China

4. School of Business, Wuyi University, Wuyishan Fujian 354300, China

5. School of Transportation Engineering, Chang'an University, Xi'an Shaaxi 710064, China 


\section{Abstract}

Improving the logistics ecological efficiency (LEE) has become a significant part of ensuring a sustainable development and tackling environmental pollution. Previous studies in the logistics industry seldom considered air pollutants and the association of spatial information. Therefore, innovatively considering $\mathrm{SO}_{2}, \mathrm{NO}_{x}$, and PM, this study adopted the Super-SBM-Undesirable model to calculate the LEE of 30 provinces in China from 2004 to 2017, and thereafter, developed information-based matrix to explore its influencing factors by using the spatial Dubin model. The results indicated that: (1) The overall LEE during the study period was low, presenting a U-shaped trend of an initial decrease and subsequent rise, and significant regional differences with the decreasing gradient pattern of the "EasternCentral-Western." (2) A spatial directionality distributed from the northeast to southwest, and a significant spatial autocorrelation were observed. (3) The industrial structure had the greatest positive influence on the local LEE, followed by the urbanization level, technology innovation level, environmental regulation, while the energy intensity was identified as the main inhibiting factor, followed by the economic level, energy structure and opening level. (4) The LEE had a significant positive spillover effect; the energy intensity and environmental regulation positively affected the LEE in neighboring areas, while the opening level had negative impacts. In addition, policy recommendations for enhancing the LEE were made.

Keywords: Logistics ecological efficiency $\cdot$ Air pollutants - Spatial information association - Spatial directionality · Spatial autocorrelation · Super-SBM-Undesirable $\cdot$ Spatial Dubin model

\section{Introduction}

After decades of high-speed development, China is now the world's second largest economy. However, the bearing pressure of China's resources and environment has approached a critical value with respect to the economic growth (Khan 2019; Zhao et al. 2020). As a supporting, strategic, and leading industry of economic development (Egilmez and Park 2014; Liang et al. 2019; Zaman and Shamsuddin 2017), China's logistics industry has experienced a rapid development since the release of the "Logistics industry Adjustment and Revitalization Plan" by the Chinese State Council in 2009. According to the China Statistics Bureau, the cumulative value of transportation, warehousing, and postal industries, which are closely related to the logistics industry, increased from 1652.24 billion yuan in 2009 to 4280.21 billion yuan in 2019 , accounting for an average of $9.39 \%$ of the national GDP per year. However, behind the rapid growth of China's logistics industry, a host of resources and energy inputs abound. The energy consumption in the logistics industry increased from 23700 tons of standard coal in 2009 to 43600 tons in 2018, accounting for an average of $8.09 \%$ in comparison to the total energy consumed in China. Under the energy characteristics of "more coal, less oil and less gas" in China, a large amount of petrochemical energy consumed by China's logistics industry has caused a severe environmental pollution (Halldórsson et al. 2010; Liang et al. 2019; Tang et al. 2018; Zaman and Shamsuddin 2017). Mobile source pollution, closely related to the logistics industry, has become an important source of environmental pollution in China (Ministry of Environmental Protection of the People's Republic of China 2020), and had resulted in pollutants including sulfur dioxide $\left(\mathrm{SO}_{2}\right)$, nitrogen oxides $\left(\mathrm{NO}_{\mathrm{x}}\right)$ and particulate matter (PM), which are culprits of air pollution (Liu et al. 2019; Rodriguez-Rey et al. 2021; Sun et al. 2019).

The "high energy consumption, high emissions and high pollution" development mode of China's logistics industry cannot concur with the requirements of protecting the ecological environment. Under the current technical conditions, environmental pollutants are still an inseparable and undesired output of the logistics industry (Rashidi and Cullinane 2019; Tang et al. 2018). It has been demonstrated that environmental problems cannot be solved by halting the economic growth. The stagnation of economic growth will result in serious economic and social problems, and will not address environmental pollution (Huang 2016). China's logistics industry must consider economic growth and ecological environment protection, and also reduce the environmental impact of the logistics industry to the barest minimum; in other words, it must minimize the emissions of environmental pollutants and achieve a higher ecological efficiency (eco-efficiency) under the given economic output conditions.

Logistics eco-efficiency (LEE) is a key indicator for assessing the sustainability level of a logistic industry, and was first proposed by Zhou et al. (2015). Based on comprehensive and scientific principles (Caiado et al. 2017), the LEE is defined as the ratio of its inputs (resource and energy) to outputs (economic and environmental). This can be used as an effective tool to measure the economic and ecological benefits of the logistics industry. Some scholars have considered carbon dioxide $\left(\mathrm{CO}_{2}\right)$ in the estimation of the LEE in China (Long et al. 2020; Zhou et al. 2015). Yet, the measurement of LEE is still lacking in accuracy, owing to the limitation of data on the emission of other pollutants. In addition, 
compared with the manufacturing and construction industry, the logistics industry has a strong spatial mobility in its operation process, with the spatial mobility of air pollutants relating to the logistics industry being stronger (Long et al. 2020). It is worth noting that the spatial dependence is comprehensively affected by geography, economy and information in the logistics industry, which is an emerging composite service industry that integrates the transportation, warehousing and information industries (Zhang et al. 2015). Therefore, as a prerequisite to improving the LEE in China, it is important to accurately measure the LEE by reasonably judging the environmental pollutant outputs of the logistics industry, and also explore its driving factors from a multi-dimensional spatial perspective, which is of great significance towards realizing the sustainable development of China's logistics industry and addressing environmental pollution issues.

The major innovations include the following: (1) This paper classified the environmental pollutants produced in the operations of logistics industries, e.g., $\mathrm{SO}_{2}, \mathrm{NO}_{\mathrm{X}}$, and $\mathrm{PM}$, and constructed the ecoefficiency measurement index system of logistics industries based on the Super-SBM-Undesirable model. (2) The four spatial weight matrices - spatial adjacency, spatial distance, economic distance and information distance were built to explore the influencing factors of LEE, using the space-time double fixed spatial Dubin model. (3) Environmental and energy issues were taken into account while exploring the impact factors of the LEE, and not just economic and social factors.

Figure 1 presents an overview of this study. The subsequent sections are ordered as follows: "Literature review" presents relevant literature. The methods and selection of related indicators are introduced in the "Research methods and indicators" section. The "Empirical analysis of LEE" section analyzes the overall and spatial features of LEE in China. The "Spatial effect analysis of factors in LEE" identifies influencing factors. The conclusions and suggestions are finally presented in the "Conclusions and policy recommendations" section.

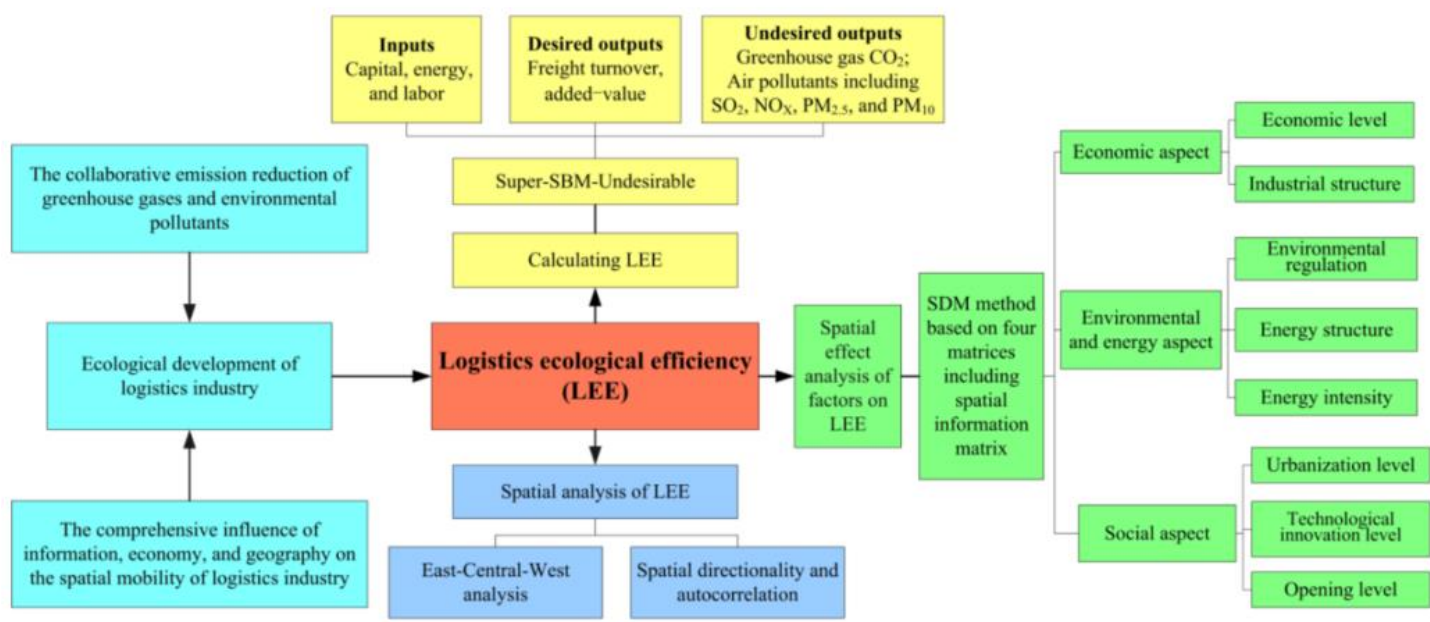

Fig. 1 The framework of the empirical study of LEE in China

\section{Literature review}

\section{Connotation and appraisal method of the LEE}

The logistics efficiency of considering eco-environmental constraints has gradually attracted the attention of scholars both in China and abroad. The existing literature employs different expressions, namely energy efficiency (Zhang et al. 2015), environmental efficiency (Fan et al. 2017), green efficiency (Liang et al. 2019), sustainable efficiency (Rashidi and Cullinane 2019; Tan et al. 2019; Tang et al. 2018) and ecological efficiency (Zhou et al. 2015; Long et al. 2020). However, since majority of them only consider the impact of $\mathrm{CO}_{2}$ or carbon emissions on the ecological environment, the connotations of these concepts are relatively similar. As an instance, Fan et al. (2019) took carbon emissions as unexpected outputs to evaluate the environmental efficiency of the Chinese logistics industry; Long et al. (2020) treated $\mathrm{CO}_{2}$ as the undesired output, and the logistics ecological efficiency of 11 provinces in the Yangtze economic belt from 2004 to 2016 was analyzed.

In these logistics efficiency concepts, eco-efficiency has a great significance to the sustainable development of the logistics industry. Schaltegger (1990) initially proposed the concept of eco-efficiency 
by emphasizing the unification of the economic and environmental benefits. Presently, more scholars regard eco-efficiency as a suitable measure for the coordinated development of the economy and environment. It has been widely employed in regional development and industries, such as agriculture, steel, tourism, transportation, energy, etc. (Caiado et al. 2017; Guan and Xu 2016; Van Caneghem et al. 2010; Zhou et al. 2018).

The current measurement methods of eco-efficiency are mainly focused on the stochastic frontier analysis (SFA) (Wang et al. 2018), ecological footprint method (Egilmez and Park 2014) and data envelopment analysis (DEA) (Kounetas et al. 2021; Yang and Zhang 2018; Zhou et al. 2018). As a nonparametric approach, the DEA method has been used continuously and extensively. Among the various DEA methods, the Super-SBM-Undesirable model has become the mainstream method owing to its nonradial and effective distinction between good and bad outputs (Caiado et al. 2017; Long et al. 2020).

\section{Influencing factors and regression method}

Presently, there are no obvious distinctions between factors that consider sustainable development and those that do not, and the types of factors remain similar. Many scholars have carried out lots of research on the economic factors of industrial structure and economic level; logistics industry factors of port logistics, infrastructure conditions and logistics human capital; and social factors of information level and urbanization rate; and a wealth of valuable results were accumulated (Hafezalkotob 2017; Long et al. 2020; Rashidi and Cullinane 2019; Tan et al. 2019; Yu and Liu 2010; Zaman and Shamsuddin 2017; Zhang et al. 2015). As an instance, taking the 18 provinces along the "Belt and Road" as study samples, Yu and Liu (2010) discovered that the regional economic level, regional marketization and port logistics can help to improve the total factor productivity of regional logistics in China. Tan et al. (2019) studied the impact of the economic development level, urbanization level, logistics resource, utilization rate and other factors on the sustainable efficiency of the logistics industry.

In the conventional research method involving the analyses of factors affecting the efficiency of industries including the logistics industry, econometric regression models such as the linear regression model (Yu and Liu 2010; Zhou et al. 2018), SFA regression model (Zhou et al. 2020) and Tobit regression model (Fujii and Managi 2013; Liang et al. 2019; Tan et al. 2019; Wang et al. 2018) are being used. However, these models ignore the pervasive spatial dependence of economics, and fail to effectively explain the influence factor of efficiency. Relatively, due to the consideration of the geographical connection between spatial units, the spatial econometric model has been widely employed in recent years (Chen et al. 2020; Long et al. 2020; Rios 2016; Guan and Xu 2016; Zhao et al. 2020). Based on the binary adjacency matrix, Guan and Xu (2016) examined the spatial spillover effects and influencing factors of energy eco-efficiency by the spatial econometric model; by constructing the weight matrix of the economic and geographic distance, Long et al. (2020) analyzed the influencing factors of the ecological efficiency of the logistics industry in the Yangtze River Economic Belt using the spatial Dubin model.

\section{General comment}

To date, considerable progress and valuable results have been achieved in relevant research of the LEE and its influence factors, but still, the following gaps exist: (1) in considering the environmental impact of the logistics industry, most existing studies only consider $\mathrm{CO}_{2}$, and ignore the $\mathrm{SO}_{2}, \mathrm{NO}_{\mathrm{x}}$, and $\mathrm{PM}$ produced in the logistics industry, failing to consider the important fact that the future of logistics industry in China will face the collaborative emission reduction of greenhouse gases and environmental pollutants. (2) These existing studies have resorted to utilizing the spatial econometric model based on geography spatial adjacency or spatial distance, and seldom utilized the nested spatial weight matrices based on information, economy and geography, while neglecting the comprehensive influence of information, economy and geography on the spatial dependence of the logistics industry. (3) In the current analysis of factors affecting the logistics efficiency, more consideration was given to economic and social factors such as economic level, industrial structure and urbanization rate, while environmental energy factors such as energy use and environmental regulation were largely ignored.

This paper has dealt with the above deficiencies and gaps in the following ways: First, the SuperSBM-Undesirable model was applied while taking the $\mathrm{CO}_{2}, \mathrm{SO}_{2}, \mathrm{NO}_{\mathrm{x}}, \mathrm{PM}_{2.5}$, and $\mathrm{PM}_{10}$ produced during the operation of the logistics industry as undesired outputs, to measure the LEE in China's 30 provinces from 2004 to 2017. Secondly, based on the four spatial weight matrices of spatial adjacency, spatial distance, economic distance and information distance, the spatial Dubin model was adopted to reveal the dominant driver of the LEE from the three aspects of economy, environmental and energy, society. 


\section{Research methods and indicators}

\section{Research regions}

The research regions cover 30 Chinese provinces (excluding Hong Kong, Macao, Taiwan and Tibet). The regions were divided into three based on the geographical location: Eastern, Central, and Western, as detailed in Fig. 2.

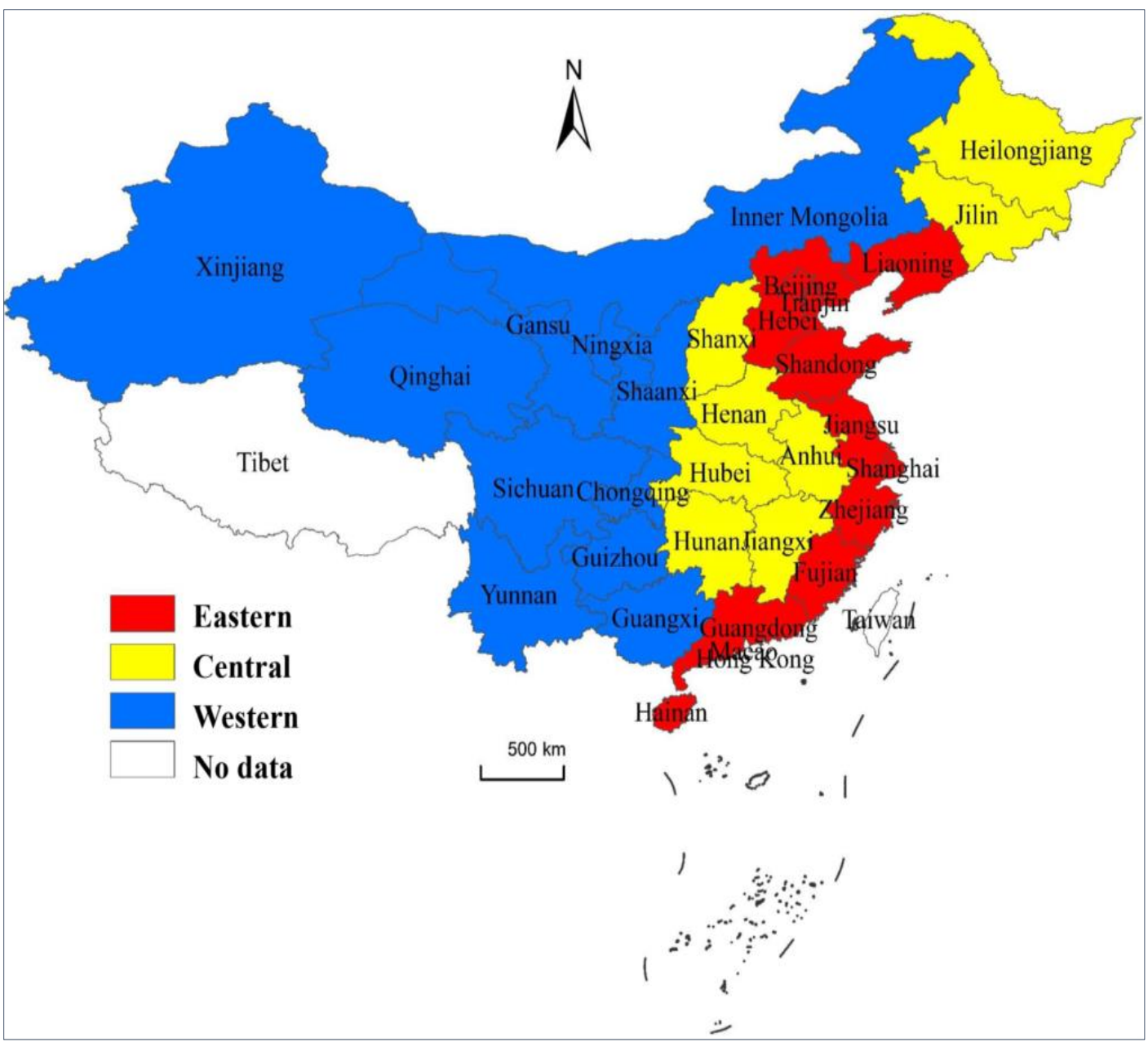

Fig. 2 Schematic diagram of the three regions of China

\section{The measurement of LEE}

Super-SBM-Undesirable

Compared with the general DEA model, the traditional SBM model (Tone 2001) takes the slack improvement of the weakly efficient decision-making unit (DMU) into account, but neglects undesirable outputs in the actual production system. The maximum efficiency of the decision-making unit is 1 . To that end, drawing on the Andersen and Petersen (1993) methods for distinguishing the efficient decisionmaking units, Tone proposed the Super-SBM model (Tone 2002) and SBM-Undesirable model (Tone 2004), where the Super-SBM-Undesirable model based on the above models was widely used to measure eco-efficiency (Caiado et al. 2017; Long et al. 2020).

Drawing on the practices of Fan et al. (2017) and Liu et al. (2019), this paper assumes that the logistics production system has $n$ DMUs, and each DMU has $m$ kinds of inputs, $q_{l}$ kinds of expected outputs and $q_{2}$ kinds of non-expected outputs. For DMUs having an efficiency value of 1 in the SBMUndesirable model, the super efficiency value was further calculated using the Super-SBM-Undesirable model.

Assuming $x^{*}=X \lambda+S^{-}, y^{w *}=Y^{w} \lambda-S^{W+}, y^{b *}=Y^{b} \lambda+S^{b-}$, the production possibility set (PPS) of logistics 
industry is:

$$
\mathrm{P}\left(x^{*}, y^{w^{*}}, y^{b *}\right)=\left\{\left(\mathrm{x}^{\prime}, y^{w^{\prime}}, y^{b \prime}\right) \mid x^{\prime} \geq \sum_{j=1, \neq 0}^{n} x_{j \lambda_{j}}, y^{w^{\prime}} \leq \sum_{j=1, \neq 0}^{n} y_{j}^{w} \lambda_{j}, y^{b \prime} \geq \sum_{j=1, \neq 0}^{n} y_{j}^{b} \lambda_{j}, y^{w \prime} \geq, y^{b \prime} \geq \lambda \geq 0\right\}
$$

where $\lambda$ denotes the non-negative intensity vecto; $\mathrm{S}\left(\mathrm{S}^{-}, \mathrm{S}^{\mathrm{W}+}, \mathrm{S}^{\mathrm{b}}\right)$ indicates the slack in inputs, desirable outputs and undesirable outputs, respectively. The Super-SBM-Undesirable is described as follows:

$$
\begin{gathered}
\min \partial^{*}=\frac{\frac{1}{m} \sum_{i=1}^{l} \frac{x_{i}^{\prime}}{x_{i 0}}}{\frac{1}{q_{1+q_{2}}}\left(\sum_{k=1}^{q_{1}} \frac{y^{w^{\prime}}}{y_{k 0}^{w}}+\sum_{k=1}^{q_{2}} \frac{y^{\mathrm{b} \prime}}{y_{k 0}^{b}}\right)} \\
\text { s.t. } \begin{cases}x^{\prime} \geq \sum_{j=1, \neq 0}^{n} x_{i j} \lambda_{j} \quad i=1,2, \ldots, l \\
y^{w^{\prime}} \leq \sum_{j=1, \neq 0}^{n} y_{k j}^{w} \lambda_{j} \quad k=1,2, \ldots, q_{1} \\
y^{b \prime} \geq \sum_{j=1, \neq 0}^{n} y_{k j}^{b} \lambda_{j} \quad k=1,2, \ldots, q_{2} \\
\mathrm{x}^{\prime} \geq x^{*}, y^{w \prime} \leq y^{w *}, y^{b^{\prime}} \geq, y^{b *}, \lambda_{j} \geq 0\end{cases}
\end{gathered}
$$

\section{The indicators and data of LEE evaluation}

In the measurement of the LEE based on the Super-SBM-Undesirable, the indexes selection of inputs, expected outputs and non-expected outputs deeply impact the overall performance (Zhou et al. 2015). Combined with the actual operation of the logistics industry and relevant references in Table 1 , the indicators of the LEE evaluation are shown in Table 2. Due to the logistics industry, statistics is incomplete in China, and referring to the research conducted by Long et al. (2020) and Yu and Liu (2010), this paper takes transportation, warehousing and postal services as an alternative, which has an $85 \%$ proportion rate in the logistics industry. The data were extracted from the China Statistic Yearbook (CSY) (2005-2018), China Energy Statistical Yearbook (CESY) (2005-2018) and Statistical Yearbooks of

\begin{tabular}{|c|c|c|c|}
\hline Inputs & Expected outputs & Non-expected outputs & Reference \\
\hline $\begin{array}{l}\text { Capital, labor, and } \\
\text { energy }\end{array}$ & $\begin{array}{l}\text { Added value, } \\
\text { freight turnover }\end{array}$ & $\mathrm{CO}_{2}$ emissions & $\begin{array}{l}\text { Green logistics total factor } \\
\text { productivity (Liang et al. 2019) }\end{array}$ \\
\hline $\begin{array}{l}\text { Investment, line, } \\
\text { energy, employees, } \\
\text { land and trucks } \\
\text { ownership }\end{array}$ & $\begin{array}{l}\text { Freight, added } \\
\text { value }\end{array}$ & $\begin{array}{l}\mathrm{CO}_{2} \text { emissions and } \\
\text { logistic accident property } \\
\text { loss }\end{array}$ & $\begin{array}{l}\text { Sustainable efficiency of } \\
\text { logistics industry (Tan et al. } \\
\text { 2019) }\end{array}$ \\
\hline $\begin{array}{l}\text { Energy, labor, capital, } \\
\mathrm{CO}_{2} \text { emissions and } \mathrm{SO}_{2} \\
\text { emissions }\end{array}$ & Added value & - & $\begin{array}{l}\text { The eco-efficiency of logistics } \\
\text { industry (Zhou et al. 2015) }\end{array}$ \\
\hline $\begin{array}{l}\text { Capital stocks, } \\
\text { employment, energy } \\
\text { and infrastructure }\end{array}$ & $\begin{array}{l}\text { Added value, } \\
\text { freight turnover }\end{array}$ & $\mathrm{CO}_{2}$ emissions & $\begin{array}{l}\text { Logistics eco-efficiency (Long } \\
\text { et al. 2020) }\end{array}$ \\
\hline- & GDP & $\begin{array}{l}\mathrm{CO}_{2}, \mathrm{SO}_{2} \text { and } \mathrm{NO}_{\mathrm{X}} \\
\text { emissions }\end{array}$ & $\begin{array}{l}\text { The eco-efficiency of US states } \\
\text { (Kounetas et al. 2021) }\end{array}$ \\
\hline $\begin{array}{l}\text { Capital, labor, energy } \\
\text { and land }\end{array}$ & GDP & $\begin{array}{l}\mathrm{SO}_{2} \text { emissions, } \\
\text { wastewater discharge, } \\
\text { smoke and dust discharge }\end{array}$ & $\begin{array}{l}\text { Urban eco-efficiency (Huang } \\
\text { 2016)) }\end{array}$ \\
\hline $\begin{array}{l}\text { Capital, labor, land, } \\
\text { water and energy }\end{array}$ & Added value & $\begin{array}{l}\text { Wastewater, exhaust gas, } \\
\text { solid waste and soot-dust }\end{array}$ & $\begin{array}{l}\text { Industrial ecological efficiency } \\
\text { (Yu et al. 2018) }\end{array}$ \\
\hline
\end{tabular}
provinces (2005-2018).

Table 1 Indicators for efficiency evaluation in relevant references

\begin{tabular}{lll}
\hline Primary indicators & Secondary-class indicators & Unit \\
\hline \multirow{3}{*}{ Inputs } & Capital stocks in logistics industry & $10^{8}$ yuan \\
& Energy consumption in logistics industry & $10^{4}$ tons of standard coal \\
& Labor force in logistics industry & Person \\
Desired outputs & Freight turnover of logistics industry & $10^{8}$ tons kilometers \\
\hline
\end{tabular}




\begin{tabular}{|c|c|c|c|}
\hline \multirow[b]{3}{*}{ Undesired outputs } & \multirow{2}{*}{\multicolumn{2}{|c|}{$\begin{array}{l}\text { Added-value of logistics industry } \\
\mathrm{CO}_{2} \text { emissions of logistics industry }\end{array}$}} & $10^{8}$ yuan \\
\hline & & & $10^{4}$ tons \\
\hline & $\begin{array}{l}\text { Environmental } \\
\text { pollution } \\
\text { index }\end{array}$ & $\begin{array}{l}\mathrm{SO}_{2} \text { emissions of logistics industry } \\
\mathrm{NO}_{\mathrm{X}} \text { emissions of logistics industry } \\
\mathrm{PM}_{2.5} \text { emissions of logistics industry } \\
\mathrm{PM}_{10} \text { emissions of logistics industry }\end{array}$ & $\begin{array}{l}10^{4} \text { tons } \\
10^{4} \text { tons } \\
10^{4} \text { tons } \\
10^{4} \text { tons }\end{array}$ \\
\hline
\end{tabular}

Inputs data:

The capital stock input was measured by the social logistics capital stock and perpetual inventory method (Dong and Wu 2019; Zhou et al. 2015), with the depreciation rate being 9.6\%. The social capital stock data were adjusted to the corresponding values based on the year 2003, while the capital stock in 2003 was calculated using the capital-output ratio backward method (Hall and Jones 1999).

The energy consumption data were obtained from the conversion and summary of the standard coal coefficients for eight types of energy (Fan et al. 2017).

Employees from the logistics industry were chosen as the labor force, referring to the total number of employees in primary.

Desired outputs data:

The data of freight turnover were obtained by summing up the highway, railway and water transport modes.

The added value of the logistics industry in all sample provinces of each year was converted into the actual value based on 2003 data.

Unexpected outputs data:

According to the energy consumption rate of the eight items in the energy balance sheets of the logistics industry, the emission factor method was used to calculate the emissions of $\mathrm{CO}_{2}, \mathrm{SO}_{2}, \mathrm{NO}_{\mathrm{X}}$, $\mathrm{PM}_{2.5}$, and $\mathrm{PM}_{10}$ by the logistics industry in 30 provinces from 2004 to 2017. The $\mathrm{CO}_{2}$ emission factors were provided by related literature (Fan et al. 2017; Sun et al. 2019), and the $\mathrm{SO}_{2}, \mathrm{NO}_{\mathrm{x}}, \mathrm{PM}_{2.5}$, and $\mathrm{PM}_{10}$ emission factors were based on the EPA, AP-42, Beijing emission coefficients (Li et al. 2018; Sun et al. 2019), and the actual situation of China's logistics industry. The above emission factors are presented in Table 3 of the Appendix.

In addition, in order to avoid the impact of high correlation and singular value, the practice of Huang et al. (2016) was considered, where the entropy weight method was used to measure the environmental pollution index of $\mathrm{SO}_{2}, \mathrm{NO}_{\mathrm{x}}, \mathrm{PM}_{2.5}$ and $\mathrm{PM}_{10}$ emissions.

\section{Spatial analysis methods}

\section{Standard deviational ellipse}

The standard deviational ellipse is a spatial econometric analysis method used to accurately reveal the spatial distribution direction features of economic attribute elements such as centrality, directionality and spreading in spatial distribution from a global perspective (Wachowicz and Liu 2016). The basic parameters of this method include the mean center, ellipse area, rotation angle, and long and short axes.

The mean center of the large region represents a point at which the weights of small, divided regions are balanced. The formulas of the weighted mean center are as follows:

$$
P_{i}\left(x_{i}, y_{i}\right)=\left(\frac{\sum_{i=1}^{n} w_{i} x_{i}}{\sum_{i=1}^{n} w_{i}}, \frac{\sum_{i=1}^{n} w_{i} y_{i}}{\sum_{i=1}^{n} w_{i}}\right)
$$

In order to show the changes in the spatial distribution of the research regions, the angle between the true north and long axes is defined as the azimuth, and the value of $\theta$ can be calculated thus:

$$
\tan \theta=\frac{\left(\sum_{i=1}^{n} w_{i}^{2} x_{i}^{*^{2}}-\sum_{i=1}^{n} w_{i}^{2} y_{i}^{*^{2}}\right)+\sqrt{\left(\sum_{i=1}^{n} w_{i}^{2} x_{i}^{* 2}-\sum_{i=1}^{n} w_{i}^{2} y_{i}^{*^{2}}\right)^{2}+4\left(\sum_{i=1}^{n} w_{i}^{2} x_{i}^{\left.*^{2} y_{i}^{* 2}\right)^{2}}\right.}}{2 \sum_{i=1}^{n} w_{i}^{2} x_{i}^{*} y_{i}^{*}}
$$

The long and short axes of the spatial distribution can be defined by calculating the standard deviations along the $\mathrm{x}$-axis and $\mathrm{y}$-axis as defined in Eqs. (4) and (5).

$$
\begin{aligned}
& \delta_{x}=\sqrt{\frac{\sum_{i=1}^{n}\left(w_{i} x_{i}^{*} \operatorname{con} \theta-w_{i} y_{i}^{*} \sin \theta\right)^{2}}{\sum_{i=1}^{n} w_{i}^{2}}} \\
& \delta_{y}=\sqrt{\frac{\sum_{i=1}^{n}\left(w_{i} x_{i}^{*} \sin \theta-w_{i} y_{i}^{*} \operatorname{con} \theta\right)^{2}}{\sum_{i=1}^{n} w_{i}^{2}}}
\end{aligned}
$$

Spatial autocorrelation analysis 

attributes, and can be used to verify the existence of spatial autocorrelation in the study area (Bai et al. 2018; Long et al. 2020; Guan and Xu 2016). The global Moran's I and local Moran's I are the two most commonly used indicators.

The paper employed the global Moran's I index to judge whether the LEE in China has a statistical agglomeration and dispersion. The value of Moran's I ranges from -1 to +1 , which indicate a perfect negative and positive autocorrelation respectively, while 0 represents no autocorrelation. Its formula is expressed as follows:

$$
\mathrm{I}=\frac{\sum_{i=1}^{n} \sum_{j=1}^{n} w_{i j}\left(x_{i}-\bar{x}\right)\left(x_{j}-\bar{x}\right)}{s^{2} \sum_{i=1}^{n} \sum_{j=1}^{n} w_{i j}}
$$

The local Moran's I index was used to assess the existence of a spatial heterogeneity in the local region of the LEE. The positive spatial autocorrelation is expressed as the HH (High-High) or LL (LowLow), while the negative spatial autocorrelation is expressed as the LH (Low-High) or HL (High-Low). Its formula is as follows:

$$
\mathrm{I}_{i}=\frac{n\left(x_{i}-\bar{x}\right) \sum_{j=1}^{k} w_{i j}\left(x_{j}-\bar{x}\right)}{\sum_{i=1}^{n}\left(x_{i}-\bar{x}\right)^{2}}(i \neq j)
$$

Where $\mathrm{n}$ is the number of research regions; $x_{i}$ and $x_{j}$ represent the observed values of LEE in regions $i$ and $j$, respectively; $w_{i j}$ stands for spatial matrix; and $k$ indicates the number of adjacent regions in a certain region.

\section{Spatial econometric model}

Spatial Dubin model

The spatial correlation and heterogeneity of panel data were considered in the spatial econometric models, making the analysis and conclusions more objective. According to Elhorst (2010), three classical spatial econometric models were included: The spatial lag model (SLM), the spatial error model (SEM) and the spatial Dubin model (SDM). The basic forms of the three models can be expressed as follows:

$$
\begin{aligned}
& y_{i t}=\alpha_{i t}+\rho W y_{i t}+x_{i t} \beta_{i t}+\varepsilon_{i t} \\
& y_{i t}=\alpha_{i t}+x_{i t} \beta_{i t}+u_{i t}, \quad u_{i t}=\lambda W u_{i t}+v_{i t} \\
& y_{i t}=\alpha_{i t}+\rho W y_{i t}+W x_{i t} \gamma_{i t}+x_{i t} \beta_{i t}+\varepsilon_{i t}
\end{aligned}
$$

Where $y_{i t}$ is the explained variable; $W$ represents the spatial matrix; $X_{i t}$ stands for the explanatory variable; $\varepsilon_{i t}$ and $v_{i t}$ are the random error term distributed with a mean of 0 and a variance of $\sigma^{2}$; and $\rho$ and $\gamma$ are spatial lag parameters. The type of spatial econometric model can be selected by the virtue of these two values being significantly 0 . When $\gamma=0$ and $\rho \neq 0$, the SDM would degenerate into SLM, while $\gamma+\rho \beta=0$, SDM will be simplified to SEM. Therefore, the SDM is more general than the SLM and SEM.

\section{Construction of spatial weight matrices}

In the spatial econometric model, different spatial weight matrices directly affect the regression results, and selecting the right matrices for the spatial econometric model is critically important (Elhorst 2010). There are two methods of generating weights in the spatial weight matrix: the contiguity (W1) and generation based on distance (W2). While the aforementioned matrices only reflect the spatial connection in geography, the influence of economic development and information technology on spatial connection is neglected, which is very important in the actual operation of the logistics industry. Therefore, in order to depict a more accurate spatial connection of the logistics industry, the practices of Li et al. (2010), Chen et al. (2020), Chen et al. (2017), and Rios (2016) were considered, with this study constructing two weight matrices based on the geographic economy (W3) and geographic information weight matrix (W4).

The data were obtained from CSY (2005-2018), and the formulas of the four spatial weight matrices are presented as follows:

$$
W 1=\left\{\begin{array}{cc}
1 & \text { Unit } \mathrm{i} \text { is adjacent with unit } \mathrm{j} \\
0 & \text { Unit } \mathrm{i} \text { is not adjacent with unit } \mathrm{j}, \text { and } \mathrm{i}=\mathrm{j}
\end{array}\right.
$$




$$
W 2=\left\{\begin{array}{cc}
1 / d_{i j} & i \neq j \\
0 & i=j
\end{array}\right.
$$

Where $d_{i j}$ denotes the euclidean distance between unit $\mathrm{i}$ and unit $\mathrm{j}$.

$$
W 3=W 2 * \operatorname{diag}\left(\frac{\bar{y}_{1}}{\bar{y}}, \frac{\bar{y}_{2}}{\bar{y}}, \ldots \ldots \frac{\bar{y}_{n}}{\bar{y}}\right)
$$

Where $W 2$ is the distance weight matrix; $\bar{y}_{\mathrm{i}}=\frac{1}{t_{1}-t_{0}+1} \sum_{t_{0}}^{t_{1}} y_{i t}$ denotes the average per capita GDP of the unit $i$ in the research period; $\overline{\mathrm{y}}=\frac{1}{t_{1} t_{0}+1} \sum_{i=1}^{n} \sum_{t_{0}}^{t_{1}} y_{i t}$ represents the average per capita GDP of all units in the research period; and the per capita GDP was unified to calculate the actual GDP value using the constant prices in 2003 .

$$
W 4=W 2 * \operatorname{diag}\left(\frac{\bar{f}_{1}}{\bar{f}}, \frac{\bar{f}_{2}}{\bar{f}}, \ldots \ldots \frac{\bar{f}_{n}}{\bar{f}}\right)
$$

Where $W 2$ is the distance weight matrix; $\bar{f}_{\mathrm{i}}=\frac{1}{t_{1}-t_{0}+1} \sum_{t_{0}}^{t_{1}} f_{i t}$ stands for the average information internet users per capita is taken as the proxy variable.

\section{Factors influencing LEE}

According to previous research, economic development provides a demand basis for the development of the logistics industry ( $\mathrm{Yu}$ and Liu 2010), while the industrial structure influences the economic growth. Therefore, the per capita GDP and the ratio of secondary industry to tertiary industry were selected to address the economic aspects of the LEE, representing the economic growth and industrial structure, respectively. The development of the logistics industry was based on the assumption that energy was cheap and sufficient in the past (Halldórsson et al. 2010), precipitating environmental contamination associated with burning fossil fuels. However, the consequences of environment degradation on the public necessitates that ecological environment protection should be included in the scope of government regulation. Thus, the environmental regulation, energy structure and energy intensity of the logistics industry were selected to analyze the environmental and energy aspects of the LEE. In addition, the level of urbanization, technological innovation and opening were also considered as social factors to explore their impact on the LEE. Eight factors influencing the LEE from three aspects are reported in Table 4. The data were collected from the CSY (2005-2018), CESY (2005-2018) and Statistical Yearbooks of provinces (2005-2018). Relevant environmental data were obtained from the China Environmental Statistics Yearbook (2005-2018).

\begin{tabular}{|c|c|c|c|}
\hline Variable type & Variable & Definition & Main references \\
\hline Economic aspect & Industrial structure (IS) & $\begin{array}{l}\text { Ratio of secondary industry to tertiary industry } \\
\text { (ratio) }\end{array}$ & $\begin{array}{l}\text { (Guan and Xu 2016; Long et al. } \\
\text { 2020) }\end{array}$ \\
\hline \multirow{2}{*}{$\begin{array}{l}\text { Environmental and } \\
\text { energy aspect }\end{array}$} & Environmental regulation (ER) & $\begin{array}{l}\text { Investment in industrial pollution as a proportion } \\
\text { of GDP }(\%)\end{array}$ & (Liang et al. 2019; Wang et al. 2018) \\
\hline & Energy intensity (EI) & $\begin{array}{l}\text { Ratio of energy consumption to the added value of } \\
\text { logistics industry (tons/ten thousand yuan) }\end{array}$ & $\begin{array}{l}\text { (Halldórsson et al. 2010; Long et al. } \\
\text { 2020) }\end{array}$ \\
\hline Social aspect & Urbanization level (UL) & $\begin{array}{l}\text { Proportion of urban population to the regional } \\
\text { total population }(\%)\end{array}$ & (Tan et al. 2019; Zhao et al. 2020) \\
\hline
\end{tabular}

Table 4 Factors influencing LEE 


\section{The overall analysis}

Based on the Super-SBM-Undesirable model and selected indexes, the LEE values of 30 provinces in China from 2004 to 2017 were calculated, and the results are presented in the Appendix Table 5. The average value of the LEE in China was observed to be equal to 0.620 , with only 11 provinces being above average, indicating the poorness of the overall LEE in China.

Figure 3 depicts the changes in the average LEE value of 30 provinces from 2004 to 2017. It clearly indicates that the LEE attained its lowest value of 0.494 in 2007, depicting a downward trend from 2004 to 2007, a fluctuating upward trend from 2007 to 2013 and a stable fluctuation between 0.659 and 0.706 after 2013. As a whole, the U-shaped trend of the "decreasing first and then rising" is presented, with the most probable reason behind this being the ineffective environmental protection policies at the national level. Since 2013, large scale haze pollution has been recorded in many cities and regions in China, prompting the implementation of a policy by the Chinese government to combine the total amount of pollutants with the concentration control, and prohibit the discharge of pollutants from exceeding the prescribed limit. Meanwhile, the environmental protection awareness of logistics enterprises was enhanced to acquire more living space, resulting in the improvement of the LEE after 2013.

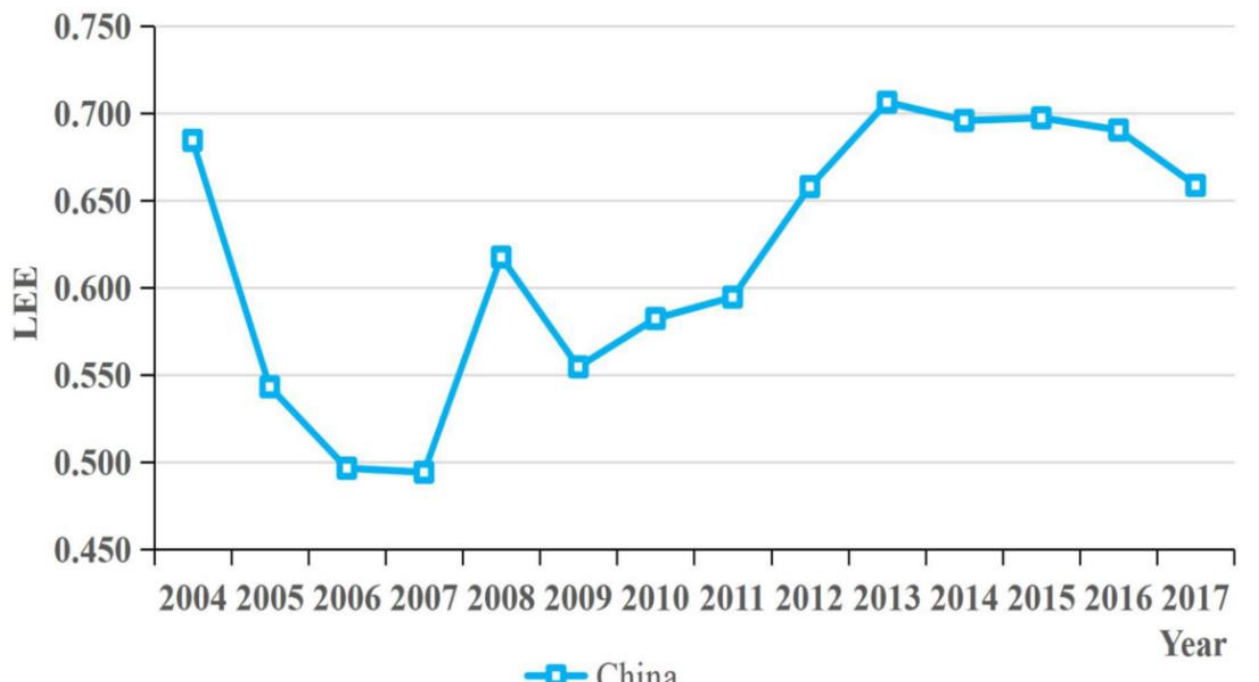

Fig. 3 The time trend of the average LEE value in China from 2004 to 2017

Figures 4, 5 and 6 show the significant differences in the LEE among the provinces, which indicates a gradual decline from Eastern to Western China, presenting a decreasing gradient pattern of "Eastern-Central-Western," and the possible reasons for this include the following:

Since reform and opening up, China had implemented an unbalanced regional development strategy, which is focused on the provision of financial policy support for the eastern region and the indirect promotion of the logistics industry's market demand and development space. On the other hand, with the rapid development of the manufacturing and logistics industry, the eastern region has attained a very high economic level, and following the enhancement in awareness of ecological and environmental protection, more funds were invested in environmental protection. In contrast, industries and enterprises having serious environmental pollution in the eastern region migrated to the central and western regions and due to the relatively backward economic development, the central and western regions were more willing to accept these enterprises and set relatively loose environmental regulation policies. The proportion of investment in environmental pollution control to GDP was still insufficient in the central and western regions, which remained at an average of $1.5 \%$ over the years and is lower than the $2-3 \%$ environmental quality improvement ratio recommended by the World Bank (1997). 


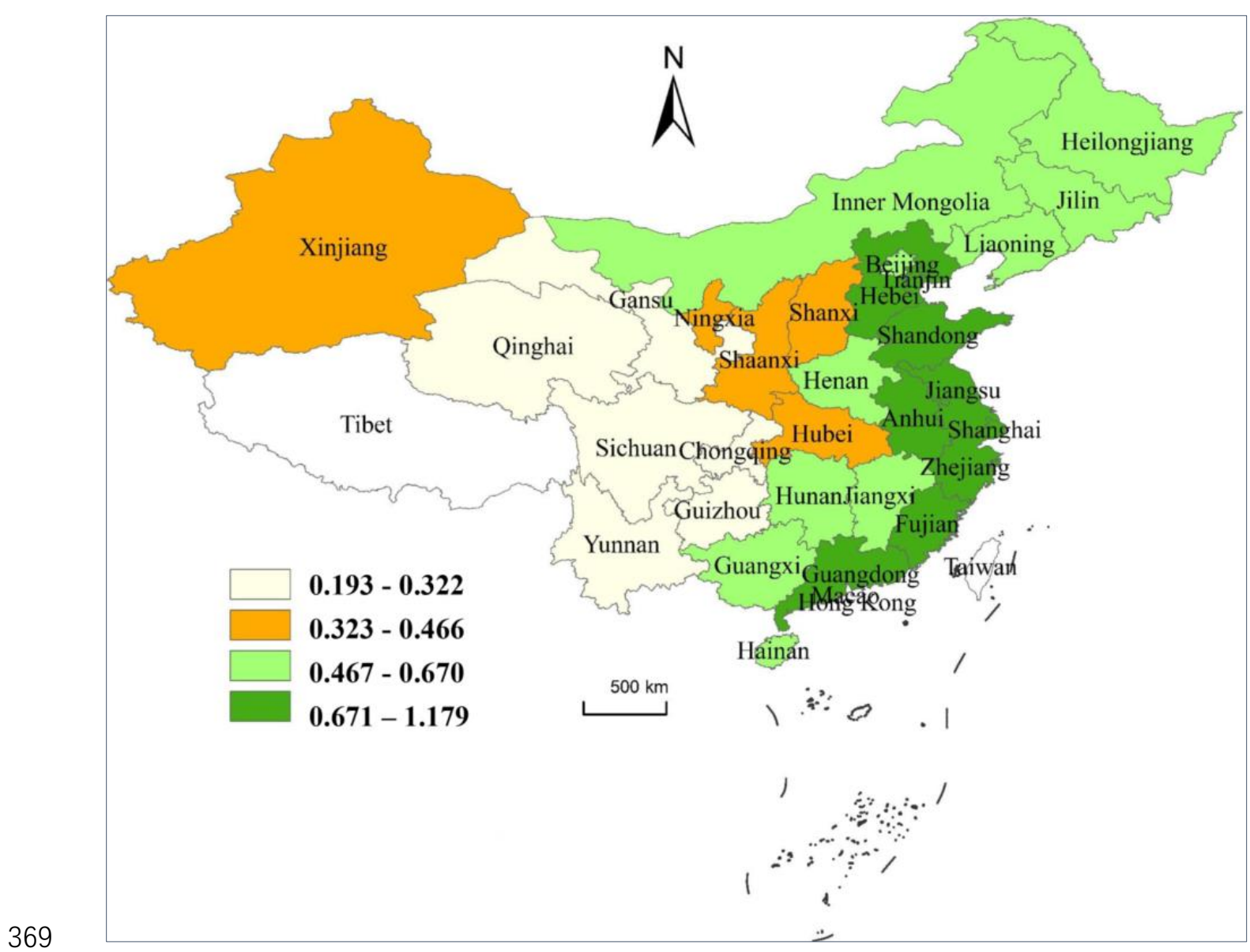




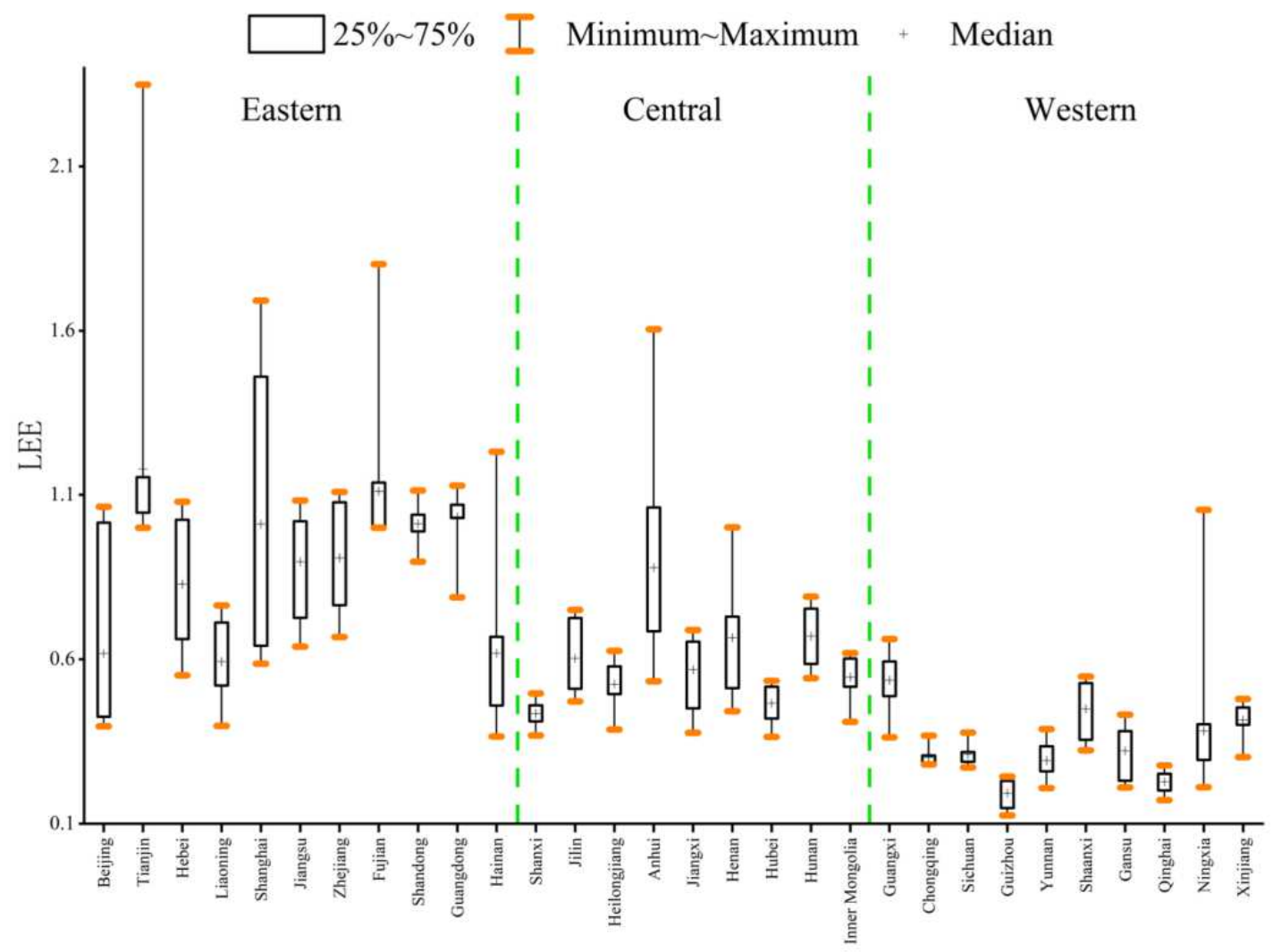

Fig.5 Boxplot of the LEE in 30 Chinese provinces, 2004-2017

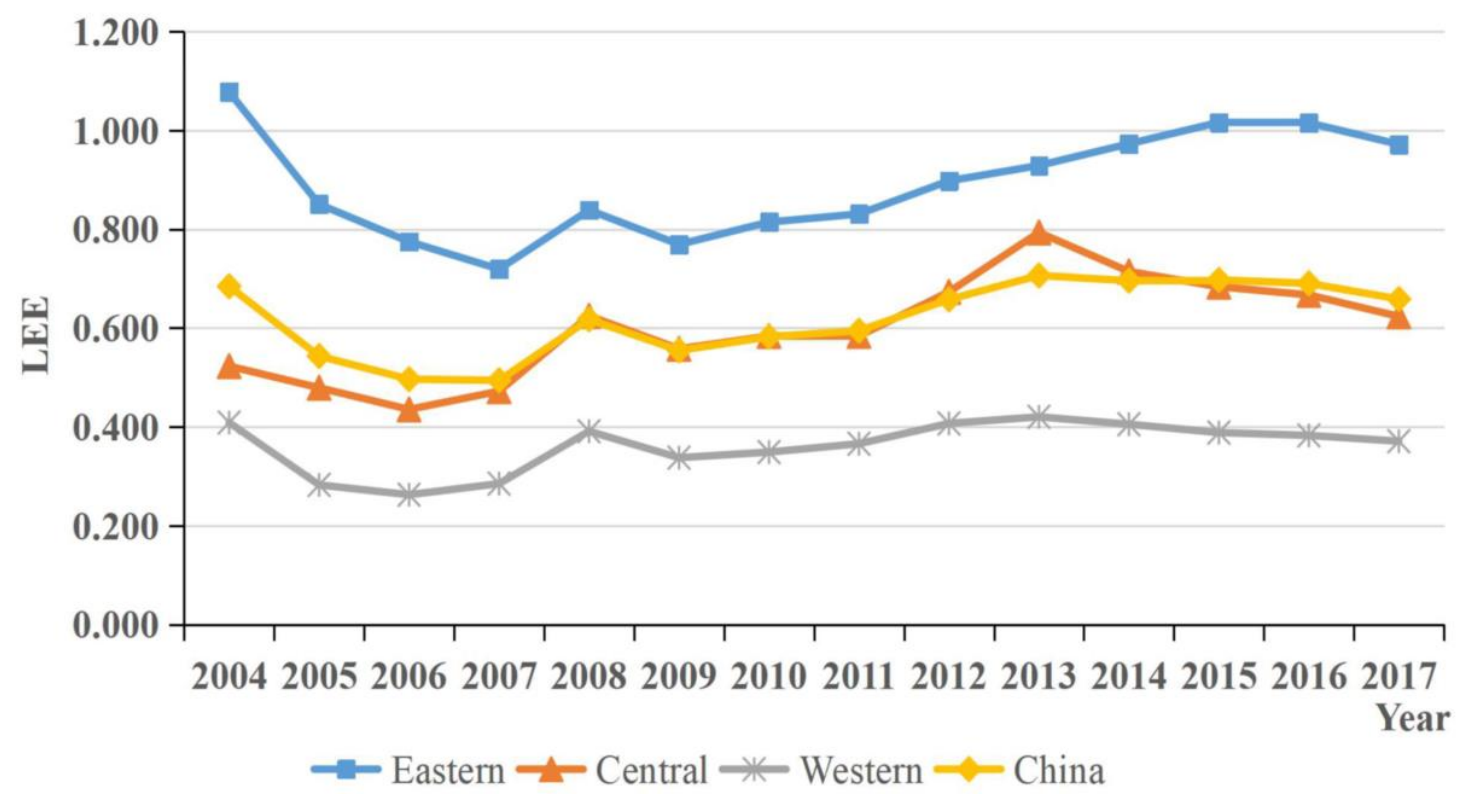

Fig.6 The evolutionary trend of LEE in the three regions of China, 2004-2017

The spatial distribution analysis

The ArcGIS10.2 software was used to calculate the LEE relative parameters of the standard deviational ellipse in 2004, 2008, 2013 and 2017, and the results are presented in Figure 7 and Table 6.

The spatial directionality of the LEE exhibited a trend of "northeast to southwest," with the center of gravity being in the Henan Province and in a consistent movement to the southeast. The values of oblateness and rotation angle increased volatilely from 2004 to 2017. On the overall, the direction of the LEE in China was obvious, and the "northeast to southwest" trend remained relatively stable. 


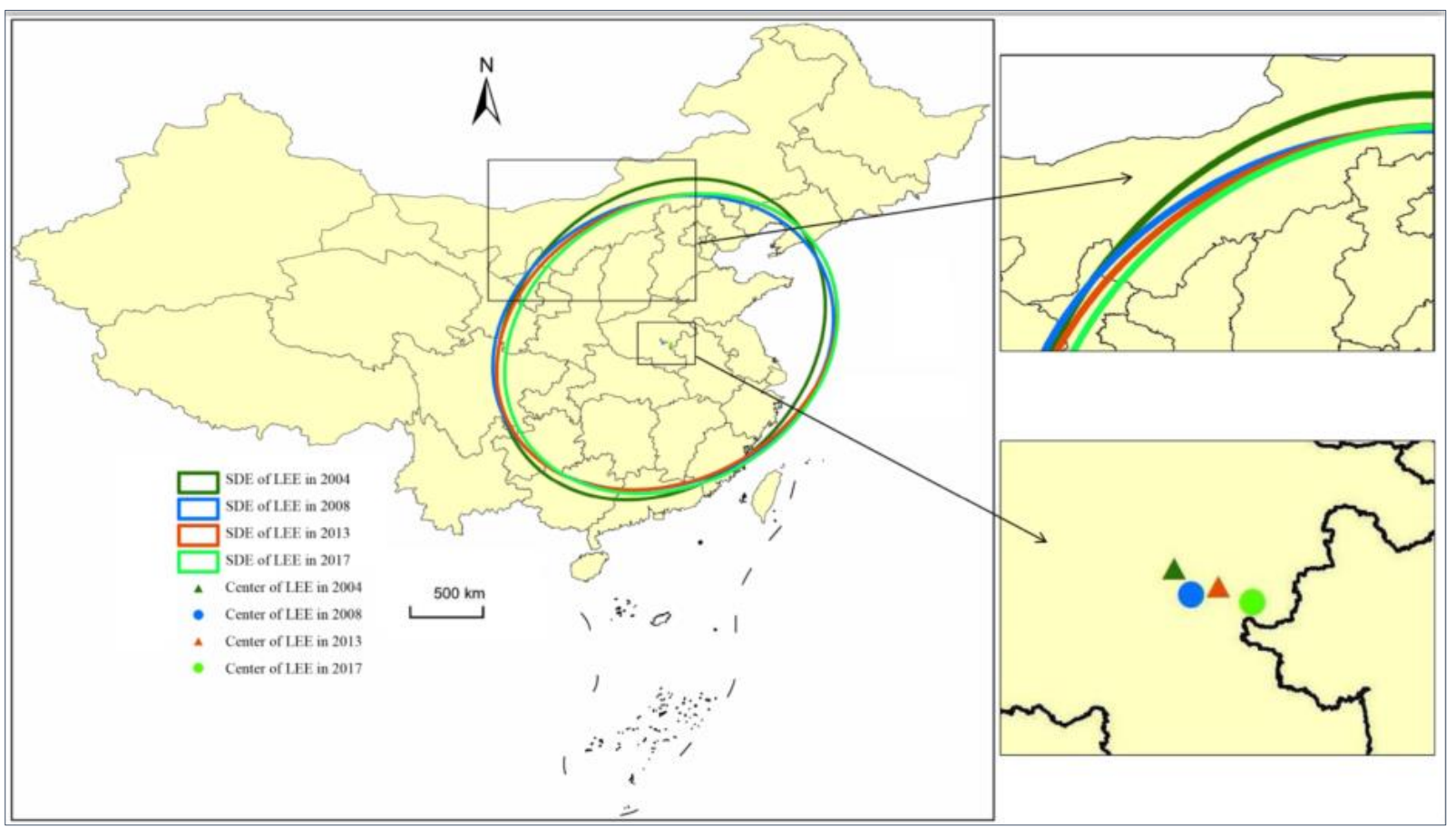

Fig. 7 Spatial trend in the standard deviational ellipses of LEE

Table 6 The main parameters of LEE standard deviational ellipse

\begin{tabular}{ccccccc}
\hline Year & X-axis & Y-axis & $\begin{array}{c}\text { X-axis } \\
\text { standard } \\
\text { deviation } \\
(\mathrm{km})\end{array}$ & $\begin{array}{c}\text { Y-axis } \\
\text { standard } \\
\text { deviation } \\
(\mathrm{km})\end{array}$ & $\begin{array}{c}\text { Rotation } \\
\text { angle } \\
(\text { degree })\end{array}$ & Oblateness \\
\hline 2004 & 114.332 & 33.559 & 9.147 & 11.289 & 47.608 & 1.234 \\
2008 & 114.468 & 33.352 & 8.935 & 11.095 & 65.636 & 1.242 \\
2013 & 114.694 & 33.408 & 8.808 & 11.229 & 62.195 & 1.275 \\
2017 & 114.978 & 33.288 & 8.880 & 11.045 & 58.907 & 1.244 \\
\hline
\end{tabular}

\section{Spatial Autocorrelation Analysis}

\section{Global Autocorrelation Analysis}

The global Moran'I was adopted to measure its spatial correlation as shown in Table 7 and Figure 8. From 2004 to 2017, the global Moran'I of the LEE was all positive and statistically significant $(p<0.01)$, indicating a significant positive correlation between the 30 provinces in China. As observed in figure 8, the global Moran'I exhibited an overall fluctuating upward trend during the study period. Moran'I attained its highest value of 0.644 in 2015, and although declining slightly, its value soared above 0.5 in 2016 and 2017. These results indicate that the LEE of China had a significant spatial agglomeration effect.

Table 7 The global Moran'I index of LEE

\begin{tabular}{ccccccccccccccc}
\hline Year & 2004 & 2005 & 2006 & 2007 & 2008 & 2009 & 2010 & 2011 & 2012 & 2013 & 2014 & 2015 & 2016 & 2017 \\
\hline Moran'I & 0.319 & 0.488 & 0.309 & 0.376 & 0.476 & 0.460 & 0.482 & 0.432 & 0.540 & 0.524 & 0.552 & 0.644 & 0.629 & 0.526 \\
P-value & 0.005 & 0.001 & 0.008 & 0.004 & 0.001 & 0.001 & 0.001 & 0.001 & 0.001 & 0.001 & 0.001 & 0.001 & 0.001 & 0.001 \\
Z & 3.087 & 4.394 & 2.797 & 3.482 & 4.270 & 4.154 & 4.359 & 3.930 & 4.828 & 4.732 & 4.911 & 5.736 & 5.569 & 4.813 \\
\hline
\end{tabular}




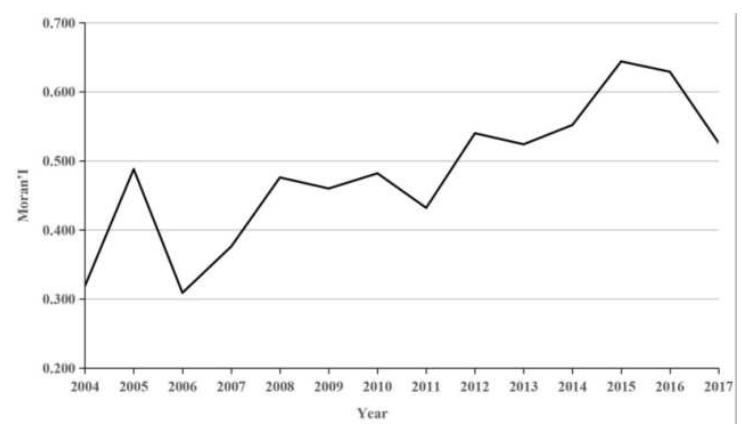

Fig. 8 The global Moran'I of LEE, 2004-2017

\section{Local autocorrelation analysis}

The local Moran'I index was mapped to display the spatial autocorrelation between a province and its neighboring provinces in 2004, 2008, 2013 and 2017, as presented in Figure 9. The results indicate that almost all provinces were either in the $\mathrm{HH}$ and LL clusters or had no obvious agglomeration, but were not in the LH and HL clusters, indicating a positive spatial autocorrelation of regions. The HH cluster area was always concentrated in the eastern coastal area of China, while the LL cluster area appeared in the western inland area. The above results indicate that the LEE in China exhibits the characteristics of local spatial agglomeration.

The possible reasons for this were speculated as follows: The economy and logistics industry in the eastern region was relatively developed and the environmental protection system was more complete, which contributed to the positive spillover effect on the surrounding provinces, resulting in a high LEE cluster. However, the western region, which is short of resources and located inland, had lagged behind the eastern region for a long time, and its readiness to develop the economy was stronger than the desire to protect the ecological environment, resulting in a low LEE cluster.

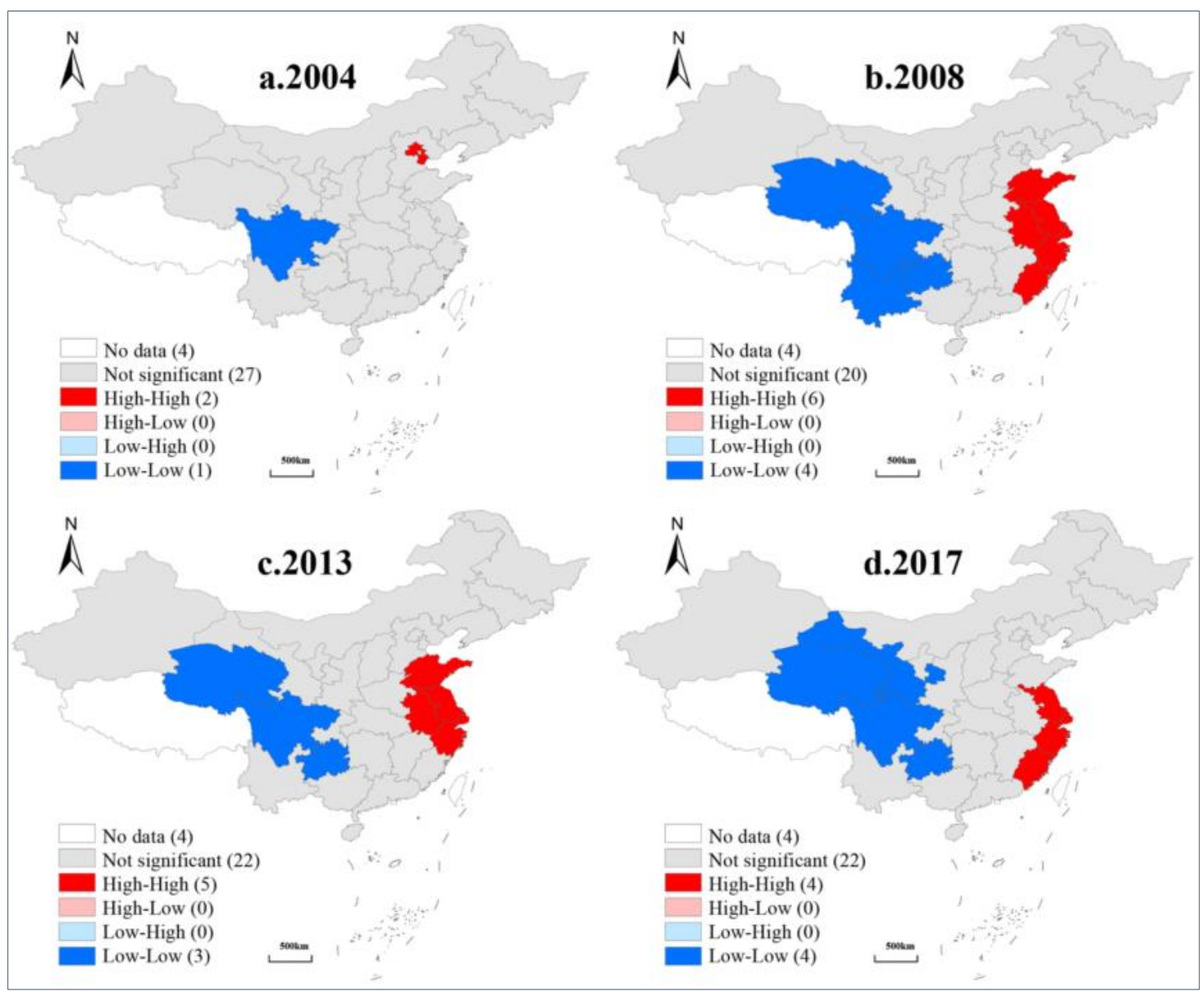

Fig.9 The local spatial autocorrelation cluster of LEE 


\section{Spatial effect analysis of factors on LEE}

\section{Selection of spatial econometric model}

416 According to the previous analysis, the LEE in China was characterized by a spatial autocorrelation, 417 indicating the necessity of the spatial econometric model. The tests to determine the tendency of the 418 SDM to degenerate into the SLM or SEM are verified under four different spatial matrices, and the 419 details are presented in Table 8. The results supported the selection of the SDM method with double 420 fixed effects in time and space.

Table 8 Test results of the spatial econometric model

\begin{tabular}{|c|c|c|c|c|}
\hline Inspection items & $\begin{array}{l}\text { Adjacency } \\
\text { matrix W1 }\end{array}$ & $\begin{array}{l}\text { Distance } \\
\text { matrix W2 }\end{array}$ & $\begin{array}{l}\text { Economic } \\
\text { matrix W3 }\end{array}$ & $\begin{array}{l}\text { Information } \\
\text { matrix W4 }\end{array}$ \\
\hline Moran's I & $\begin{array}{l}6.072 * * * \\
(0.000)\end{array}$ & $\begin{array}{l}5.860 * * * \\
(0.000)\end{array}$ & $\begin{array}{l}158.902 * * * \\
(0.000)\end{array}$ & $\begin{array}{l}144.563 * * * \\
(0.000)\end{array}$ \\
\hline LMLAG & $\begin{array}{l}33.224 * * * \\
(0.000)\end{array}$ & $\begin{array}{l}30.266^{* * * *} \\
(0.000)\end{array}$ & $\begin{array}{l}27.571 \text { *** } \\
(0.000)\end{array}$ & $\begin{array}{l}24.447 * * * \\
(0.000)\end{array}$ \\
\hline R-LMLAG & $\begin{array}{l}0.046 \\
(0.830)\end{array}$ & $\begin{array}{l}0.038 \\
(0.830)\end{array}$ & $\begin{array}{l}0.000 \\
(0.999)\end{array}$ & $\begin{array}{l}2.593 \\
(0.107)\end{array}$ \\
\hline LMERR & $\begin{array}{l}80.497 * * * \\
(0.000)\end{array}$ & $\begin{array}{l}62.323^{* * * *} \\
(0.000)\end{array}$ & $\begin{array}{l}51.245^{* * *} \\
(0.000)\end{array}$ & $\begin{array}{l}25.369^{* * *} \\
(0.000)\end{array}$ \\
\hline R-LMERR & $\begin{array}{l}47.319^{* * * *} \\
(0.000)\end{array}$ & $\begin{array}{l}32.095^{* * * *} \\
(0.000)\end{array}$ & $\begin{array}{l}23.675 * * * \\
(0.000)\end{array}$ & $\begin{array}{l}3.515^{*} \\
(0.061)\end{array}$ \\
\hline Wald-slm & $\begin{array}{l}63.44 * * * \\
(0.000)\end{array}$ & $\begin{array}{l}45.14^{* * * *} \\
(0.000)\end{array}$ & $\begin{array}{l}43.16^{* * * *} \\
(0.000)\end{array}$ & $\begin{array}{l}43.16 * * * \\
(0.000)\end{array}$ \\
\hline Wald-sem & $\begin{array}{l}59.46^{* * * *} \\
(0.000)\end{array}$ & $\begin{array}{l}42.23 * * * \\
(0.000)\end{array}$ & $\begin{array}{l}40.64 * * * \\
(0.000)\end{array}$ & $\begin{array}{l}40.64 * * * \\
(0.000)\end{array}$ \\
\hline LR- slm & $\begin{array}{l}59.22 * * * \\
(0.000)\end{array}$ & $\begin{array}{l}42.85 * * * \\
(0.000)\end{array}$ & $\begin{array}{l}41.05^{* * *} \\
(0.000)\end{array}$ & $\begin{array}{l}41.05 * * * \\
(0.000)\end{array}$ \\
\hline LR-sem & $\begin{array}{l}59.61 * * * \\
(0.000)\end{array}$ & $\begin{array}{l}40.36^{* * * *} \\
(0.000)\end{array}$ & $\begin{array}{l}38.90 * * * \\
(0.000)\end{array}$ & $\begin{array}{l}38.90 * * * \\
(0.000)\end{array}$ \\
\hline Hausman & $\begin{array}{r}18.309 * * \\
(0.019)\end{array}$ & $\begin{array}{c}16.93 * * \\
(0.031)\end{array}$ & $\begin{array}{l}18.77 * * \\
(0.016)\end{array}$ & $\begin{array}{l}18.77 * * \\
(0.016)\end{array}$ \\
\hline LR-ind & $\begin{array}{l}67.47 * * * \\
(0.000)\end{array}$ & $\begin{array}{l}37.34 * * * \\
(0.000)\end{array}$ & $\begin{array}{l}37.55^{* * * *} \\
(0.000)\end{array}$ & $\begin{array}{l}37.55 * * * \\
(0.000)\end{array}$ \\
\hline LR-time & $\begin{array}{l}326.37 * * * \\
(0.000)\end{array}$ & $\begin{array}{l}346.50 * * * \\
(0.000)\end{array}$ & $\begin{array}{l}344.33 * * * \\
(0.000)\end{array}$ & $\begin{array}{l}344.33 * * * \\
(0.000)\end{array}$ \\
\hline
\end{tabular}

Notes: $* * *$ significant at $1 \%$ level; $* *$ significant at $5 \%$ level; * significant at $10 \%$ level.

\section{Analysis of SDM regression results}

424 Based on the SDM, the factors influencing the LEE were analyzed and results are presented in Table 9, with the prefix " $\mathrm{Ln}$ " denoting the natural logarithm. It is noteworthy that the average amount of variance $\left(\mathrm{R}^{2}\right)$ is a pseudo value in the spatial econometric model, which is unsuitable for the evaluation of the model fit degree. Therefore, the log likelihood (Log-L) ratio test is adopted (Bai et al. 2018). Given the value of Log-L from Table 9, the SDM model with double fixed effects in time and space was selected as the best-fit model. The regression coefficients of the spatial lag term (Spatial-rho) under four unique spatial matrices were positively significant $(p<0.05)$, indicating the presence of a significant spatial spillover effect on the LEE in the Chinese provinces. The improvement of the LEE in the surrounding provinces would promote the progress of the local LEE, and the local LEE could also increase with the enhancement of the LEE in the surrounding provinces.

Table 9 Estimation results of the SDM model based on four spatial weight matrices

\begin{tabular}{lllll}
\hline Variables & $\begin{array}{l}\text { Adjacency } \\
\text { matrix W1 }\end{array}$ & $\begin{array}{l}\text { Distance } \\
\text { matrix W2 }\end{array}$ & $\begin{array}{l}\text { Economic } \\
\text { matrix W3 }\end{array}$ & $\begin{array}{l}\text { Information } \\
\text { matrix W4 }\end{array}$ \\
\hline \multirow{2}{*}{ LnEL } & $-0.3598 * *$ & $-0.4096 * *$ & $-0.3506 * *$ & $-0.2989 *$ \\
& $(-2.3051)$ & $(-2.5594)$ & $(-2.1998)$ & $(-1.8913)$ \\
\multirow{2}{*}{ LnIS } & $0.3134 * * *$ & $0.2770 * * *$ & $0.2506 * * *$ & $0.2353 * * *$ \\
& $(4.6432)$ & $(3.7474)$ & $(3.4187)$ & $(3.2343)$ \\
\hline
\end{tabular}




\begin{tabular}{|c|c|c|c|c|}
\hline LnER & $\begin{array}{l}0.0929 * * * \\
(5.9154)\end{array}$ & $\begin{array}{l}0.0892 * * * \\
(5.4365)\end{array}$ & $\begin{array}{l}0.0876^{* * * *} \\
(5.3352)\end{array}$ & $\begin{array}{l}0.0892^{* * *} \\
(5.4792)\end{array}$ \\
\hline LnES & $\begin{array}{l}-0.0864 * * \\
(-2.2944)\end{array}$ & $\begin{array}{l}-0.1466 \text { *** } \\
(-3.8919)\end{array}$ & $\begin{array}{l}-0.1482 * * * \\
(-3.9395)\end{array}$ & $\begin{array}{l}-0.1393 \text { *** } \\
(-3.7296)\end{array}$ \\
\hline LnEI & $\begin{array}{l}-0.4028 * * * \\
(-10.1046)\end{array}$ & $\begin{array}{l}-0.3887 * * * \\
(-9.6745)\end{array}$ & $\begin{array}{l}-0.3929 * * * \\
(-9.7777)\end{array}$ & $\begin{array}{l}-0.3901 * * * \\
(-9.7853)\end{array}$ \\
\hline LnUL & $\begin{array}{l}0.1682 \\
(1.2012)\end{array}$ & $\begin{array}{l}0.2595 * * \\
(2.0142)\end{array}$ & $\begin{array}{l}0.2167^{*} \\
(1.6912)\end{array}$ & $\begin{array}{l}0.1989 \\
(1.5792)\end{array}$ \\
\hline LnTIL & $\begin{array}{l}0.1184^{* * * *} \\
(3.1775)\end{array}$ & $\begin{array}{l}0.0873 * * \\
(2.3403)\end{array}$ & $\begin{array}{l}0.0813 * * \\
(2.1772)\end{array}$ & $\begin{array}{l}0.0758^{* *} \\
(2.0658)\end{array}$ \\
\hline LnOL & $\begin{array}{l}-0.0861 * * * \\
(-2.7440)\end{array}$ & $\begin{array}{l}-0.0856 * * * \\
(-2.6917)\end{array}$ & $\begin{array}{l}-0.0875 \text { *** } \\
(-2.7445)\end{array}$ & $\begin{array}{l}-0.0862 * * * \\
(-2.7201)\end{array}$ \\
\hline $\mathrm{W} * \mathrm{LnEL}$ & $\begin{array}{l}1.0307 * * * \\
(3.7213)\end{array}$ & $\begin{array}{l}0.5868 \\
(1.5759)\end{array}$ & $\begin{array}{l}0.5238 \\
(1.4574)\end{array}$ & $\begin{array}{l}0.5033 \\
(1.4616)\end{array}$ \\
\hline W*LnIS & $\begin{array}{l}-0.0924 \\
(-0.6231)\end{array}$ & $\begin{array}{l}-0.1161 \\
(-0.5814)\end{array}$ & $\begin{array}{l}-0.2051 \\
(-0.9956)\end{array}$ & $\begin{array}{l}-0.2105 \\
(-1.0257)\end{array}$ \\
\hline $\mathrm{W} * \mathrm{LnER}$ & $\begin{array}{l}0.0907 * * * \\
(2.7673)\end{array}$ & $\begin{array}{l}0.0909 * * \\
(2.0639)\end{array}$ & $\begin{array}{l}0.1064 * * \\
(2.3853)\end{array}$ & $\begin{array}{l}0.1116^{* * * *} \\
(2.6073)\end{array}$ \\
\hline $\mathrm{W} * \mathrm{LnES}$ & $\begin{array}{l}0.2393 \text { *** } \\
(2.9403)\end{array}$ & $\begin{array}{l}-0.0236 \\
(-0.2258)\end{array}$ & $\begin{array}{l}0.0098 \\
(0.0905)\end{array}$ & $\begin{array}{l}0.0898 \\
(0.8176)\end{array}$ \\
\hline $\mathrm{W} * \mathrm{LnEI}$ & $\begin{array}{l}0.2843^{* * *} * \\
(3.2266)\end{array}$ & $\begin{array}{l}0.5028^{* * *} \\
(4.2823)\end{array}$ & $\begin{array}{l}0.5295^{* * *} \\
(4.3129)\end{array}$ & $\begin{array}{l}0.5719^{* * * *} \\
(4.4636)\end{array}$ \\
\hline $\mathrm{W} * \mathrm{LnUL}$ & $\begin{array}{l}0.1642 \\
(0.6063)\end{array}$ & $\begin{array}{l}-0.3394 \\
(-1.1683)\end{array}$ & $\begin{array}{l}-0.1479 \\
(-0.5097)\end{array}$ & $\begin{array}{l}-0.1336 \\
(-0.4559)\end{array}$ \\
\hline $\mathrm{W}^{*} \mathrm{LnTIL}$ & $\begin{array}{l}0.0175 \\
(0.2455)\end{array}$ & $\begin{array}{l}0.1414 \\
(1.4623)\end{array}$ & $\begin{array}{l}0.1403 \\
(1.4286)\end{array}$ & $\begin{array}{l}0.1489 \\
(1.5152)\end{array}$ \\
\hline $\mathrm{W} * \mathrm{LnOL}$ & $\begin{array}{l}0.0011 \\
(0.0140)\end{array}$ & $\begin{array}{l}-0.1382 \\
(-1.4769)\end{array}$ & $\begin{array}{l}-0.1562 * \\
(-1.6526)\end{array}$ & $\begin{array}{l}-0.1640 * \\
(-1.6517)\end{array}$ \\
\hline Spatial-rho & $\begin{array}{l}0.1452 * * \\
(2.0558)\end{array}$ & $\begin{array}{l}0.1677 * * \\
(2.0996)\end{array}$ & $\begin{array}{l}0.1769 * * \\
(2.2265)\end{array}$ & $\begin{array}{l}0.1765^{* * *} \\
(2.3604)\end{array}$ \\
\hline $\begin{array}{l}\text { Variance- } \\
\text { sigma2_e }\end{array}$ & $\begin{array}{l}0.0193^{* * * *} \\
(14.4423)\end{array}$ & $\begin{array}{l}0.0201 * * * \\
(14.4561)\end{array}$ & $\begin{array}{l}0.0202 * * * \\
(14.4512)\end{array}$ & $\begin{array}{l}0.0200^{* * * *} \\
(14.5389)\end{array}$ \\
\hline $\log -\mathrm{L}$ & 231.9650 & 223.2985 & 222.6149 & 223.1256 \\
\hline
\end{tabular}

Notes: $* * *$ significant at $1 \%$ level; $* *$ significant at $5 \%$ level; * significant at $10 \%$ level.

However, special attention was directed to the fact that the SDM model contains dependent variables of the spatial lag term. Consequently, a change in the independent variable for a local province may affect it and the surrounding provinces, and in turn, have other effects on the original province. Therefore, the regression coefficients in Table 9 cannot accurately depict the real marginal effect of the independent variables. To this end, the best practices in existing literature were referred to (Chen et al. 2017; Rios 2016), and using partial differential decomposition methods, the estimates of direct, indirect and total effects were obtained to analyze the impact of the independent variables on the LEE of local and surrounding provinces. Detailed results are presented in Table 10.

Table 10 SDM spatial spillover effect decomposition

\begin{tabular}{llllll}
\hline & Variables & $\begin{array}{l}\text { Adjacency } \\
\text { matrix W1 }\end{array}$ & $\begin{array}{l}\text { Distance } \\
\text { matrix W2 }\end{array}$ & $\begin{array}{l}\text { Economic } \\
\text { matrix W3 }\end{array}$ & $\begin{array}{l}\text { Information } \\
\text { matrix W4 }\end{array}$ \\
\hline \multirow{2}{*}{ Direct } & \multirow{2}{*}{ LnEL } & $-0.3224^{* *}$ & $-0.3928^{* *}$ & $-0.3351^{* *}$ & $-0.2841^{*}$ \\
& & $(-2.0591)$ & $(-2.4208)$ & $(-2.0724)$ & $(-1.7699)$ \\
& \multirow{2}{*}{ LnIS } & $0.3052^{* * *}$ & $0.2679^{* * *}$ & $0.2387^{* * *}$ & $0.2235^{* * *}$ \\
& & $(5.1366)$ & $(3.9698)$ & $(3.5746)$ & $(3.3999)$ \\
& \multirow{2}{*}{ LnER } & $0.0981^{* * *}$ & $0.0937^{* * * *}$ & $0.0927^{* * *}$ & $0.0943^{* * *}$ \\
& & $(5.7473)$ & $(5.1963)$ & $(5.1174)$ & $(5.2337)$ \\
& \multirow{2}{*}{ LnES } & $-0.0746^{*}$ & $-0.1449^{* * *}$ & $-0.1456^{* * *}$ & $-0.1343^{* * *}$ \\
& $(-1.7483)$ & $(-3.4660)$ & $(-3.4819)$ & $(-3.2193)$ \\
\hline
\end{tabular}




\begin{tabular}{|c|c|c|c|c|c|}
\hline & LnEI & $\begin{array}{l}-0.4012^{* * *} \\
(-8.4283)\end{array}$ & $\begin{array}{l}-0.3822^{* * *} \\
(-7.8195)\end{array}$ & $\begin{array}{l}-0.3852^{* * *} \\
(-7.8879)\end{array}$ & $\begin{array}{l}-0.3816^{\text {*** }} \\
(-7.8433)\end{array}$ \\
\hline & LnUL & $\begin{array}{l}0.1836 \\
(1.4275)\end{array}$ & $\begin{array}{l}0.2582^{* *} \\
(2.1428)\end{array}$ & $\begin{array}{l}0.2207^{*} \\
(1.8382)\end{array}$ & $\begin{array}{l}0.2033^{*} \\
(1.7237)\end{array}$ \\
\hline & LnTIL & $\begin{array}{l}0.1212^{\text {*** }} \\
(3.2936)\end{array}$ & $\begin{array}{l}0.0930^{* *} \\
(2.5525)\end{array}$ & $\begin{array}{l}0.0870^{* *} \\
(2.3786)\end{array}$ & $\begin{array}{l}0.0816^{* *} \\
(2.2770)\end{array}$ \\
\hline & LnOL & $\begin{array}{l}-0.0903^{\text {*** }} \\
(-2.9578)\end{array}$ & $\begin{array}{l}-0.0940^{* * *} \\
(-3.0663)\end{array}$ & $\begin{array}{l}-0.0966^{* * *} \\
(-3.1422)\end{array}$ & $\begin{array}{l}-0.0954^{\text {*** }} \\
(-3.1199)\end{array}$ \\
\hline \multirow[t]{8}{*}{ Indirect } & LnEL & $\begin{array}{l}1.1375^{\text {*** }} \\
(4.0213)\end{array}$ & $\begin{array}{l}0.6340 \\
(1.5965)\end{array}$ & $\begin{array}{l}0.5720 \\
(1.4746)\end{array}$ & $\begin{array}{l}0.5594 \\
(1.5145)\end{array}$ \\
\hline & LnIS & $\begin{array}{l}-0.0565 \\
(-0.3605)\end{array}$ & $\begin{array}{l}-0.0920 \\
(-0.4094)\end{array}$ & $\begin{array}{l}-0.1999 \\
(-0.8401)\end{array}$ & $\begin{array}{l}-0.2084 \\
(-0.8669)\end{array}$ \\
\hline & LnER & $\begin{array}{l}0.1219^{* * *} \\
(3.0013)\end{array}$ & $\begin{array}{l}0.1283^{* *} \\
(2.3071)\end{array}$ & $\begin{array}{l}0.1485^{* * *} \\
(2.6380)\end{array}$ & $\begin{array}{l}0.1544^{\text {**** }} \\
(2.9166)\end{array}$ \\
\hline & LnES & $\begin{array}{l}0.2579^{* *} \\
(2.5467)\end{array}$ & $\begin{array}{l}-0.0591 \\
(-0.4489)\end{array}$ & $\begin{array}{l}-0.0220 \\
(-0.1589)\end{array}$ & $\begin{array}{l}0.0766 \\
(0.5521)\end{array}$ \\
\hline & LnEI & $\begin{array}{l}0.2433^{* *} \\
(2.4000)\end{array}$ & $\begin{array}{l}0.5039^{* * *} \\
(3.5723)\end{array}$ & $\begin{array}{l}0.5364^{* * *} \\
(3.5824)\end{array}$ & $\begin{array}{l}0.5878^{\text {*** }} \\
(3.7560)\end{array}$ \\
\hline & LnUL & $\begin{array}{l}0.2351 \\
(0.8072)\end{array}$ & $\begin{array}{l}-0.3096 \\
(-0.9286)\end{array}$ & $\begin{array}{l}-0.0886 \\
(-0.2645)\end{array}$ & $\begin{array}{l}-0.0769 \\
(-0.2295)\end{array}$ \\
\hline & LnTIL & $\begin{array}{l}0.0384 \\
(0.4726)\end{array}$ & $\begin{array}{l}0.1802 \\
(1.5493)\end{array}$ & $\begin{array}{l}0.1799 \\
(1.4995)\end{array}$ & $\begin{array}{l}0.1889 \\
(1.5443)\end{array}$ \\
\hline & $\mathrm{LnOL}$ & $\begin{array}{l}-0.0128 \\
(-0.1357)\end{array}$ & $\begin{array}{l}-0.1806^{*} \\
(-1.6541)\end{array}$ & $\begin{array}{l}-0.2044^{*} \\
(-1.8167)\end{array}$ & $\begin{array}{l}-0.2119^{*} \\
(-1.7979)\end{array}$ \\
\hline \multirow[t]{8}{*}{ Total } & LnEL & $\begin{array}{l}0.8151^{* * *} \\
(2.6125)\end{array}$ & $\begin{array}{l}0.2412 \\
(0.5380)\end{array}$ & $\begin{array}{l}0.2369 \\
(0.5352)\end{array}$ & $\begin{array}{l}0.2753 \\
(0.6421)\end{array}$ \\
\hline & LnIS & $\begin{array}{l}0.2487 \\
(1.4127)\end{array}$ & $\begin{array}{l}0.1759 \\
(0.6722)\end{array}$ & $\begin{array}{l}0.0388 \\
(0.1423)\end{array}$ & $\begin{array}{l}0.0151 \\
(0.0554)\end{array}$ \\
\hline & LnER & $\begin{array}{l}0.2199^{* * *} \\
(4.8489)\end{array}$ & $\begin{array}{l}0.2220^{* * * *} \\
(3.6015)\end{array}$ & $\begin{array}{l}0.2411^{* * *} \\
(3.8513)\end{array}$ & $\begin{array}{l}0.2486^{\text {**** }} \\
(4.1787)\end{array}$ \\
\hline & LnES & $\begin{array}{l}0.1833 \\
(1.5251)\end{array}$ & $\begin{array}{l}-0.2040 \\
(-1.3906)\end{array}$ & $\begin{array}{l}-0.1676 \\
(-1.0963)\end{array}$ & $\begin{array}{l}-0.0577 \\
(-0.3761)\end{array}$ \\
\hline & LnEI & $\begin{array}{l}-0.1579 \\
(-1.3072)\end{array}$ & $\begin{array}{l}0.1217 \\
(0.7462)\end{array}$ & $\begin{array}{l}0.1511 \\
(0.8888)\end{array}$ & $\begin{array}{l}0.2062 \\
(1.1724)\end{array}$ \\
\hline & LnUL & $\begin{array}{l}0.4187 \\
(1.5054)\end{array}$ & $\begin{array}{l}-0.0513 \\
(-0.1474)\end{array}$ & $\begin{array}{l}0.1321 \\
(0.3730)\end{array}$ & $\begin{array}{l}0.1263 \\
(0.3583)\end{array}$ \\
\hline & LnTIL & $\begin{array}{l}0.1596^{*} \\
(1.8083)\end{array}$ & $\begin{array}{l}0.2732^{* *} \\
(2.3248)\end{array}$ & $\begin{array}{l}0.2669^{* *} \\
(2.2116)\end{array}$ & $\begin{array}{l}0.2705^{* *} \\
(2.1956)\end{array}$ \\
\hline & $\mathrm{LnOL}$ & $\begin{array}{l}-0.1031 \\
(-0.9619)\end{array}$ & $\begin{array}{l}-0.2746^{* *} \\
(-2.2516)\end{array}$ & $\begin{array}{l}-0.3010^{* *} \\
(-2.4050)\end{array}$ & $\begin{array}{l}-0.3073^{* *} \\
(-2.3597)\end{array}$ \\
\hline
\end{tabular}

Under the four different spatial matrices, the direct effect of the economic level (EL) on the LEE was negative with an average coefficient of -0.3336 , which satisfies the significance level test of $10 \%$, with the indirect and total effects being insignificant. This conclusion disagrees with Tang et al. (2018), Long et al. (2020), but agrees with Zhou et al. (2018). This indicates that the high economic level of a certain region will promote the development of its logistics industry, but will not necessarily improve the region's LEE. A possible reason for this is due to China's economy being in a period of unbalanced and extensive development. The extensive economic growth had enlarged the development scale of the logistics industry, but failed to bring about the green ecological development of the logistics industry, while the high economic level had resulted in a reduced LEE.

The direct effect of the industrial structure (IS) on LEE under the four different spatial matrices was positive, given an average coefficient of -0.2588 , which is significant at the $1 \%$ level, while the indirect and total effects were insignificant. The yielded results accorded with the findings of Zhu et al. (2011) and Zhu et al. (2020), indicating the significant improvement of the local LEE on the secondary industry, with no significant impact on the LEE of surrounding areas. The possible reason could be due to the dependency of the development of the logistics industry on the circulation of industrial products in China. However, following the upgrade of the industrial structure and the development of the tertiary industry, the effect of the logistics industry's scale will be adversely affected in the short term, resulting in a decrease in LEE. This result enforces that the industrial restructuring of China should not overemphasize 
the rapid scale expansion of the tertiary industry, but should pay more attention to the integration and linkage development of the tertiary and logistics industries.

Based on the four different spatial matrices, the direct and indirect effects of environmental regulation (ER) on the LEE were positive, with average coefficients of 0.0947 and 0.1383 , respectively, which were significant at the $1 \%$ level. These results were consistent with the conclusion of Tang et al. (2018) and Zhao et al. (2020), indicating that the investment in pollution control would significantly improve the LEE of local and surrounding areas. This suggests that an increased investment in pollution control in a certain area could significantly promote the LEE in that region and its surrounding regions. Therefore, the environmental expenditure of China is expected to continue spiraling.

Only the direct effect of the energy structure (ES) passed the 1\% significance level test under the three different spatial matrices other than the W1, indicating a negative effect and an average coefficient of -0.1249 . This indicates that the use of power energy in the logistics industry had no boosting effect on the local LEE in any way. The possible reason could lie in the fact that electricity energy comes from unclean energy sources including coal, which is classified as "rich coal, less oil and less gas" in China. The electric energy consumed by the logistics industry is not really clean. This result suggests that green electricity from clean energy sources such as wind, water and solar energy, as opposed to the "black electricity" from coal should be used in the ecological green development of future logistics industries.

The energy intensity (EI) had a significant negative direct effect and a positive indirect effect on the LEE under four different spatial matrices, with average coefficient values of -0.3876 and 0.4679 , respectively, which were significant at the $5 \%$ level. The results indicate that each $1 \%$ decrease in energy intensity results in a corresponding increase in the local LEE by $0.3876 \%$, but may result in the decrease in the LEE of the surrounding provinces by $0.4679 \%$. This may be due to the fact that the rapid development of China's logistics industry depends on a large amount of energy consumption. In the case of kerosene, gasoline and the "black electricity" dominating the energy consumption of China's logistics industry, energy intensity cannot be used as a lone indicator because it enhances the local LEE, while also inhibiting the LEE of surrounding areas. This requires the logistics industry to reduce its energy intensity and focus more on green electricity to control the negative spillover effect.

Under the three different spatial matrices other than $\mathrm{W} 1$, only the direct effect of the urbanization level (UL) passed the 10\% significance level test, indicating a positive effect and an average coefficient of -0.2274 . This result indicates that the urbanization level significantly promotes the local LEE, which is consistent with the study by Tan et al. (2019). The possible reasons for this are ascribed as follows: The improvement of urbanization levels had granted free access to a large number of rural inhabitants to migrate to urban areas, consequently providing abundant human resources for the logistics industry. On the other hand, urbanization resulted in the overpopulation of the city, which increases the expectations of people for beautiful environments, thereby encouraging the implementation of environmental protection measures by the government and logistics enterprises.

The Technological Innovation Level (TIL) had a significant positive direct effect on the LEE with an average coefficient of 0.0957 , under four different spatial matrices. This indicates a pass of the significance test at the 5\% level, and verifies previous research conclusions from Zhou et al. (2018). Through an upgrade in the production mode of enterprises and the lifestyle of individuals, technological innovations can improve the resource utilization and industrial production efficiencies, and also reduce the environmental pollution caused by economic development.

The average coefficients of the direct and indirect effects of opening level (OL) based on four matrices were -0.9471 and -0.1990 , respectively. This is nearly at the $10 \%$ significance level, indicating that an increase in the foreign direct investment will inhibit the LEE of a certain area and its surroundings, which supports the "pollution haven hypothesis." This result suggests the establishment of strict environmental admission standards for open projects in the process of opening up, as opposed to blindly attracting foreign investment.

\section{Conclusions and Policy Recommendations}

\section{Conclusions}

By employing the Super-SBM-Undesirable and Spatial Dubin models, this study measures the LEE of 30 provinces in China from 2004 to 2017, and also explores its influencing factors. The conclusions are as follows: 
First, the LEE is at a low level on the overall, depicting a U-shaped trend of "initial decrease before rising" during the study period. This shows significant regional differences among the 30 provinces and a gradual decline from Eastern to Western China.

Second, the spatial directionality of the LEE depicts a "northeast to southwest" trend, with the LEE having a significant positive spatial autocorrelation and agglomeration in the geographical distribution.

Third, the industrial structure has the greatest positive impact on the local LEE, succeeded by the urbanization level, technological innovation level and environmental regulation; energy intensity has the largest negative impact on the local LEE, followed by economic level, energy structure and opening level.

Fourth, the LEE has a significant positive spatial spillover effect due to the positive impact of energy intensity and environmental regulation on the LEE in neighboring provinces, and a significant inhibiting impact of opening level on the LEE of surrounding areas.

\section{Policy Recommendations}

First, significant regional differences of the LEE in China exist, necessitating the formulation of differentiated ecological efficiency improvement strategies. Eastern provinces should focus on innovative research and development of environmental pollutant emission reduction technology in the logistics industry, and actively provide emission reduction technologies, talents and financial support to the central and western regions. By combining the resource advantages of their logistics industry, the central and western regions should facilitate the development of a secondary industry, improve the urbanization level, actively introduce an emission reduction technology and focus on increasing investment in pollution control.

Second, the development of the secondary industry has the greatest promotional effect on the LEE, and the integration and linkage development of the secondary and logistics industries should be vigorously encouraged. The government should focus on accelerating the pace of green development of intelligent manufacturing, establishing the two-industry linkage information service platform and building the collaborative green cycle system of industry and supply chains in the manufacturing industry.

Third, there exists a restraining impact of energy intensity and energy structure on the LEE; therefore, the energy utilization efficiency in the logistics industry should be further improved. As an industry having a high energy consumption, the logistics industry should emphasize on the use of black electricity from coal and focus more on the use of green electricity from clean energy such as wind, water, and solar energy to speed up the ecological development of the logistics industry.

Fourth, since the LEE has a positive spatial spillover effect among the Chinese provinces, a joint prevention and control mechanism of environmental management in the logistics industry should be established. The government should consider integrated elements such as economic base, openness level, energy characteristics, traffic and location conditions, energy use and transportation location in neighboring provinces. Pollutant emissions at key positions of logistics channels and hubs should be accurately prevented and controlled, daily environmental monitoring and supervision should be intensified, ecological logistics demonstration projects in cross-regional urban agglomerations should be implemented, and the full potentials of government policies should be maximized.

\section{Declarations}

557 Ethics approval and consent to participate: Not applicable

558 Consent for publication: Not applicable

559 Data availability: The datasets used and analysed during the current study are available from the corresponding author upon reasonable request.

561 Competing interests: The authors declare no competing interests

562 Funding: This work was supported by the Key Project of the National Social Science Foundation of China (grant no.20AJY015), the Fundamental Research Funds for the Central Universities (grant no.300102341667) and Soft Science Research Plan of Zhengzhou city (grant no.2020PKXF0111)

Authors' contributions: Bai was responsible for the conception and design of the study, and was the main writer of the manuscript; Khan and Chen interpreted the results; Wang and Yang contributed to the discussion and revisions; and Dong reviewed and supervised the manuscript. All authors read and approved the final manuscript. 
Table 3 The emission factors of $\mathrm{CO}_{2}, \mathrm{SO}_{2}, \mathrm{NOx}, \mathrm{PM}_{2.5}$ and $\mathrm{PM}_{10}$

\begin{tabular}{ccccccccc}
\hline $\begin{array}{c}\text { Energy } \\
\text { types }\end{array}$ & Raw coal & $\begin{array}{c}\text { Other coal } \\
\text { washing }\end{array}$ & Coke & Crude oil & Gasoline & Diesel & Fuel oil & $\begin{array}{c}\text { Natural } \\
\text { gas }\end{array}$ \\
\hline Unit & $\mathrm{kg} / \mathrm{t}$ & $\mathrm{Kg} / \mathrm{t}$ & $\mathrm{Kg} / \mathrm{t}$ & $\mathrm{Kg} / \mathrm{t}$ & $\mathrm{Kg} / \mathrm{t}$ & $\mathrm{Kg} / \mathrm{t}$ & $\mathrm{Kg} / \mathrm{t}$ & $\mathrm{Kg} / \mathrm{t}$ \\
$\mathrm{CO}_{2}$ & 2.81 & 2.96 & 3.13 & 2.15 & 2.04 & 2.17 & 2.26 & 1.64 \\
$\mathrm{SO}_{2}$ & 10.0 & 10.0 & 19.0 & 2.75 & 1.6 & 2.24 & 2.24 & 0.18 \\
$\mathrm{NO}_{\mathrm{X}}$ & 4.0 & 4.0 & 4.8 & 5.09 & 16.7 & 9.62 & 5.84 & 2.1 \\
$\mathrm{PM}_{2.5}$ & 0.74 & 0.74 & 0.144 & 0.06 & 0.125 & 0.31 & 0.31 & 0.15 \\
$\mathrm{PM}_{10}$ & 1.61 & 1.61 & 0.288 & 1.6 & 0.25 & 0.31 & 0.31 & 0.22 \\
\hline
\end{tabular}

Table 5 The LEE of 30 provinces in China from 2004 to 2017

\begin{tabular}{|c|c|c|c|c|c|c|c|c|c|c|c|c|c|c|c|}
\hline Provin & 2004 & 2005 & 2006 & 2007 & 2008 & 2009 & 2010 & 2011 & 2012 & 2013 & 2014 & 2015 & 2016 & 2017 & Mean \\
\hline Beijing & 1.063 & 1.026 & 0.425 & 0.405 & 0.396 & 0.398 & 0.426 & 0.445 & 0.432 & 0.512 & 0.502 & 1.018 & 1.015 & 0.574 & 0.617 \\
\hline Tianjin & 2.349 & 1.119 & 1.184 & 1.056 & 1.005 & 1.032 & 1.132 & 1.225 & 1.154 & 1.000 & 1.082 & 1.055 & 1.045 & 1.066 & 1.179 \\
\hline Hebei & 1.000 & 0.600 & 0.551 & 0.579 & 0.794 & 0.661 & 0.679 & 0.690 & 0.794 & 1.017 & 1.055 & 1.024 & 1.079 & 1.069 & 0.828 \\
\hline Shanxi & 0.432 & 0.404 & 0.368 & 0.411 & 0.496 & 0.437 & 0.411 & 0.396 & 0.418 & 0.460 & 0.460 & 0.454 & 0.448 & 0.486 & 0.434 \\
\hline Inner Mongolia & 0.565 & 0.445 & 0.409 & 0.425 & 0.601 & 0.527 & 0.516 & 0.536 & 0.618 & 0.612 & 0.596 & 0.590 & 0.607 & 0.590 & 0.546 \\
\hline Liaoning & 0.520 & 0.450 & 0.397 & 0.423 & 0.609 & 0.521 & 0.562 & 0.562 & 0.663 & 0.763 & 0.717 & 0.711 & 0.724 & 0.665 & 0.592 \\
\hline Jilin & 0.609 & 0.498 & 0.472 & 0.516 & 0.498 & 0.510 & 0.537 & 0.593 & 0.661 & 0.745 & 0.749 & 0.730 & 0.725 & 0.588 & 0.602 \\
\hline Heilongjiang & 0.499 & 0.439 & 0.386 & 0.437 & 0.504 & 0.496 & 0.531 & 0.494 & 0.546 & 0.606 & 0.624 & 0.625 & 0.578 & 0.576 & 0.524 \\
\hline Shanghai & 0.647 & 0.619 & 0.586 & 0.588 & 1.177 & 0.641 & 0.697 & 0.725 & 1.166 & 1.172 & 1.460 & 1.479 & 1.500 & 1.691 & 1.011 \\
\hline Jiangsu & 0.673 & 0.673 & 0.638 & 0.726 & 0.817 & 0.884 & 1.019 & 1.040 & 1.083 & 1.029 & 1.017 & 1.012 & 1.001 & 0.937 & 0.896 \\
\hline Zhejiang & 0.764 & 0.726 & 0.667 & 0.719 & 0.863 & 0.811 & 0.875 & 0.892 & 0.944 & 1.096 & 1.068 & 1.109 & 1.105 & 1.077 & 0.908 \\
\hline Anhui & 0.685 & 0.617 & 0.533 & 0.541 & 1.043 & 0.724 & 0.752 & 0.689 & 1.017 & 1.605 & 1.216 & 1.062 & 1.062 & 0.757 & 0.879 \\
\hline Fujian & 1.802 & 1.123 & 1.050 & 1.000 & 1.000 & 1.000 & 1.000 & 1.000 & 1.000 & 1.052 & 1.058 & 1.168 & 1.158 & 1.137 & 1.111 \\
\hline Jiangxi & 0.450 & 0.425 & 0.377 & 0.401 & 0.605 & 0.552 & 0.575 & 0.606 & 0.689 & 0.670 & 0.679 & 0.642 & 0.628 & 0.653 & 0.568 \\
\hline Shandong & 1.018 & 1.020 & 1.017 & 1.019 & 1.113 & 1.074 & 1.079 & 1.039 & 1.007 & 0.987 & 1.007 & 0.988 & 0.908 & 0.897 & 1.012 \\
\hline Henan & 0.512 & 0.482 & 0.442 & 0.496 & 0.717 & 0.676 & 0.729 & 0.746 & 0.834 & 1.001 & 0.712 & 0.679 & 0.646 & 0.647 & 0.666 \\
\hline Hubei & 0.420 & 0.393 & 0.364 & 0.389 & 0.444 & 0.440 & 0.491 & 0.503 & 0.534 & 0.525 & 0.523 & 0.516 & 0.488 & 0.492 & 0.466 \\
\hline Hunan & 0.577 & 0.574 & 0.542 & 0.586 & 0.690 & 0.628 & 0.644 & 0.646 & 0.687 & 0.736 & 0.754 & 0.761 & 0.762 & 0.790 & 0.670 \\
\hline Guangdong & 0.788 & 1.000 & 1.007 & 1.031 & 1.036 & 1.044 & 1.031 & 1.029 & 1.064 & 1.070 & 1.069 & 1.079 & 1.128 & 1.089 & 1.033 \\
\hline Guangxi & 0.488 & 0.448 & 0.363 & 0.442 & 0.568 & 0.508 & 0.524 & 0.537 & 0.574 & 0.661 & 0.616 & 0.589 & 0.594 & 0.593 & 0.536 \\
\hline Hainan & 1.231 & 1.000 & 1.000 & 0.365 & 0.419 & 0.395 & 0.459 & 0.492 & 0.570 & 0.523 & 0.668 & 0.535 & 0.504 & 0.489 & 0.618 \\
\hline Chongqing & 0.332 & 0.300 & 0.280 & 0.285 & 0.367 & 0.301 & 0.308 & 0.295 & 0.313 & 0.283 & 0.290 & 0.285 & 0.293 & 0.291 & 0.302 \\
\hline Sichuan & 0.302 & 0.285 & 0.271 & 0.287 & 0.348 & 0.315 & 0.295 & 0.318 & 0.345 & 0.377 & 0.318 & 0.314 & 0.289 & 0.289 & 0.311 \\
\hline Guizhou & 0.125 & 0.140 & 0.139 & 0.148 & 0.214 & 0.180 & 0.179 & 0.183 & 0.217 & 0.241 & 0.243 & 0.230 & 0.234 & 0.225 & 0.193 \\
\hline Yunnan & 0.388 & 0.238 & 0.209 & 0.225 & 0.261 & 0.259 & 0.264 & 0.274 & 0.316 & 0.354 & 0.337 & 0.335 & 0.317 & 0.311 & 0.292 \\
\hline Shaanxi & 0.355 & 0.327 & 0.323 & 0.351 & 0.449 & 0.392 & 0.415 & 0.547 & 0.504 & 0.542 & 0.529 & 0.527 & 0.508 & 0.516 & 0.449 \\
\hline Gansu & 0.231 & 0.220 & 0.210 & 0.224 & 0.381 & 0.311 & 0.333 & 0.338 & 0.414 & 0.432 & 0.407 & 0.361 & 0.334 & 0.310 & 0.322 \\
\hline Qinghai & 0.218 & 0.185 & 0.172 & 0.183 & 0.264 & 0.225 & 0.243 & 0.235 & 0.272 & 0.252 & 0.277 & 0.232 & 0.226 & 0.201 & 0.227 \\
\hline Ningxia & 1.054 & 0.213 & 0.211 & 0.226 & 0.432 & 0.294 & 0.332 & 0.309 & 0.424 & 0.402 & 0.380 & 0.362 & 0.364 & 0.339 & 0.382 \\
\hline Xinjiang & 0.438 & 0.307 & 0.302 & 0.340 & 0.416 & 0.401 & 0.429 & 0.453 & 0.479 & 0.468 & 0.465 & 0.450 & 0.442 & 0.415 & 0.415 \\
\hline Eastern & 1.078 & 0.851 & 0.775 & 0.719 & 0.839 & 0.769 & 0.815 & 0.831 & 0.898 & 0.929 & 0.973 & 1.016 & 1.015 & 0.972 & 0.891 \\
\hline
\end{tabular}




\begin{tabular}{cccccccccccccccc}
\hline Central & 0.523 & 0.479 & 0.435 & 0.472 & 0.625 & 0.558 & 0.584 & 0.584 & 0.673 & 0.793 & 0.715 & 0.684 & 0.667 & 0.624 & 0.601 \\
Western & 0.409 & 0.282 & 0.263 & 0.285 & 0.391 & 0.338 & 0.349 & 0.366 & 0.407 & 0.420 & 0.405 & 0.388 & 0.383 & 0.371 & 0.361 \\
China & 0.684 & 0.543 & 0.496 & 0.494 & 0.618 & 0.555 & 0.582 & 0.595 & 0.658 & 0.706 & 0.696 & 0.697 & 0.690 & 0.659 & 0.620 \\
\hline
\end{tabular}

\section{Reference}

Andersen P, Petersen NC (1993) A Procedure for Ranking Efficient Units in Data Envelopment Analysis. Manag Sci 39:1261-1264. https://doi.org/10.1287/mnsc.39.10.1261

Bai G, Yang T, Zhang X, Xun H (2018) Spatial econometric analysis on determinants of development differences between provincial logistics industry. J Beijing Jiaotong Univ (Soc Sci) 17:93-100. https://doi.org/10.16797/j.cnki.11-5224/c.2018.0003

Caiado RGG, De Freitas Dias R, Mattos LV, Quelhas OLG, Leal Filho W (2017) Towards sustainable development through the perspective of eco-efficiency - A systematic literature review. J Clean Prod 165:890-904. https://doi.org/10.1016/j.jclepro.2017.07.166

Chen C, Sun Y, Lan Q, Jiang F (2020) Impacts of industrial agglomeration on pollution and ecological efficiency-A spatial econometric analysis based on a big panel dataset of China's 259 cities. J Clean Prod 258:120721. https://doi.org/10.1016/j.jclepro.2020.120721

Chen WY, Hu FZY, Li X, Hua J (2017) Strategic interaction in municipal governments' provision of public green spaces: A dynamic spatial panel data analysis in transitional China. Cities 71:1-10. https://doi.org/10.1016/j.cities.2017.07.003

China Statistical Bureau,The China Statistic Yearbook(2005-2020), http://www.stats.gov.cn/tjsj/ndsj/ [Accessed 16 October 2020]

Dong X, Wu C (2019) Estimation of potential economic measurement of potential economic growth rate of Chinese major central cities. Statistics \& Decision 35: 118-122. https://doi.org/10.13546/j.cnki.tjyjc.2019.12.029

Egilmez G, Park YS (2014) Transportation related carbon, energy and water footprint analysis of U.S. manufacturing: An eco-efficiency assessment. Transp Res Part D: Transp Environ 32:143-159. https://doi.org/10.1016/j.trd.2014.07.001

Elhorst JP (2010) Applied Spatial Econometrics: Raising the Bar. Spat Econ Anal 5: 9-28. https://doi.org/10.1080/17421770903541772

Fan J, Xiao H, Fan X (2017) A modified three - stage DEA model with undesirable output considerationan empirical analysis based on Chinese provincial logistics efficiency. Chinese Journal of Management Science 25:166-174. https://doi.org/10.16381/j.cnki.issn1003-207X.2017.08.018

Fujii H, Managi S (2013) Determinants of eco-efficiency in the Chinese industrial sector. J Environ Sci 25:S20-S26. https://doi.org/10.1016/s1001-0742(14)60619-7

Guan W, Xu S (2016) Study of spatial patterns and spatial effects of energy eco-efficiency in China.J Geogr Sci 26(9):1362-1376. https://doi.org/10.1007/s11442-016-1332-X

Hafezalkotob A (2017) Competition, cooperation, and coopetition of green supply chains under regulations on energy saving levels. Transp Res Part E: Log Transp Rev 97:228-250. https://doi.org/10.1016/j.tre.2016.11.004

Hall RE, Jones CI (1999) Why do Some Countries Produce So Much More Output Per Worker than Others? Quart J Econ 114:83-116. https://doi.org/10.1162/003355399555954

Halldórsson Á, Halldórsson Á, Kovács G (2010) The sustainable agenda and energy efficiency. Int J Phys Distrib Logist Manag 40:5-13. https://doi.org/10.1108/09600031011018019 
Huang J (2016) Regional heterogeneity, eco-efficiency and green development in China. China Social Sciences Press, Beijing.

Khan SAR (2019) The nexus between carbon emissions, poverty, economic growth, and logistics operations-empirical evidence from southeast Asian countries. Environ Sci Pollut Res 26:1321013220. https://doi.org/10.1007/s11356-019-04829-4

Kounetas KE, Polemis ML, Tzeremes NG (2021) Measurement of eco-efficiency and convergence: Evidence from a non-parametric frontier analysis. Eur J Oper Res 291: 365-378. https://doi.org/10.1016/j.ejor.2020.09.024

Li J, Tan Q, Bai J (2010) Spatial econometric analysis of regional innovation production in China: An empirical study based on static and dynamic spatial panel models. Management World: 43-55+65. https://doi.org/10.19744/j.cnki.11-1235/f.2010.07.006

Li L, Lei Y, Wu S, Huang Z, Luo J, Wang Y, Chen J, Yan D (2018) Evaluation of future energy consumption on PM2.5 emissions and public health economic loss in Beijing. J Clean Prod 187:1115-1128. https://doi.org/10.1016/j.jclepro.2018.03.229

Liang Z, Chiu Y-h, Li X, Guo Q, Yun Y (2019) Study on the Effect of Environmental Regulation on the Green Total Factor Productivity of Logistics Industry from the Perspective of Low Carbon. Sustainability 12:175-194. https://doi.org/10.3390/su12010175

Liu X, Guo P, Guo S (2019) Assessing the eco-efficiency of a circular economy system in China's coal mining areas: Emergy and data envelopment analysis. J Clean Prod 206:1101-1109. https://doi.org/10.1016/j.jclepro.2018.09.218

Long R, Ouyang H, Guo H (2020) Super-slack-based measuring data envelopment analysis on the spatial-temporal patterns of logistics ecological efficiency using global Malmquist Index model. Environ Technol Innov 18:100770-100783. https://doi.org/10.1016/j.eti.2020.100770

Ministry of Environmental Protection of the People's Republic of China(2020) Communique of China's Second China Pollution Source Survey Bulletin, http://www.mee.gov.cn/xxgk2018/xxgk/xxgk01/202006/t20200610_783547.html [Accessed 2 November 2020]

Rashidi K, Cullinane K (2019) Evaluating the sustainability of national logistics performance using Data Envelopment Analysis. Transp Policy 74:35-46. https://doi.org/10.1016/j.tranpol.2018.11.0 14

Rios V (2016) What drives unemployment disparities in European regions? A dynamic spatial panel approach. Reg Stud 51:1599-1611. https://doi.org/10.1080/00343404.2016.1216094

Rodriguez-Rey D, Guevara M, Linares MP, Casanovas J, Salmerón J, Soret A, Jorba O, Tena C, Pérez García-Pando C (2021) A coupled macroscopic traffic and pollutant emission modelling system for Barcelona. Transp Res Part D: Transp Environ 92:102725-102742. https://doi.org/10.1016/j.trd.2021.102725

Schaltegger S, Sturm A (1990) Ökologische rationalität: Ansatzpunkte zur ausgestaltung von ökologieorientierten managementinstrumenten. Die Unternehmung 44:273-290.

Sun H, Hu X, Nie F (2019) Environment, resource properties and corresponding cost of arable land resulted from grain production in China. Chinese Journal of Environmental Management 11:71-78. https://doi.org/10.16868/j.cnki.1674-6252.2019.04.071

Tan L, Wu Q, Li Q, Cheng W, Gu Y (2019) A panel analysis of the sustainability of logistics industry in China: based on non-radial slacks-based method. Environ Sci Pollut Res 26:21948-21963. https://doi.org/10.1007/s11356-019-05481-8

Tang J, Du J, Tang Y (2018) Research on sustainable development of regional logistics efficiency under 
environmental regulation. Review of Economy and Management 34:138-149. https://doi.org/10.13962/j.cnki.37-1486/f.2018.05.014

Tone K (2001) A slacks-based measure of efficiency in data envelopment analysis. Eur J Oper Res 130:498-509. https://doi.org/10.1016/s0377-2217(99)00407-5

Tone K (2002) A slacks-based measure of super-efficiency in data envelopment analysis. Eur J Oper Res 143:32-41. https://doi.org/10.1016/s0377-2217(01)00324-1

Tone K (2004) Dealing with Undesirable Outputs in DEA: A Slacks-Based Measure (SBM) Approach. Toronto. https://doi.org/10.1007/978-1-4419-6151-8_8

Van Caneghem J, Block C, Cramm P, Mortier R, Vandecasteele C (2010) Improving eco-efficiency in the steel industry: The ArcelorMittal Gent case. J Clean Prod 18:807-814. https://doi.org/10.1016/j.jclepro.2009.12.016

Wachowicz M, Liu T (2016) Finding spatial outliers in collective mobility patterns coupled with social ties. International Journal of Geographical Information Science 30:1806-1831. https://doi.org/10.1080/13658816.2016.1144887

Wang D, Wan K, Yang J (2018) Ecological efficiency of coal cities in China: evaluation and influence factors. Natural Hazards 95:363-379. https://doi.org/10.1007/s11069-018-3441-6

World Bank (1997) World development report, https://data.worldbank.org/ [Accessed 8 January 2020]

Yang L, Zhang X (2018) Assessing regional eco-efficiency from the perspective of resource, environmental and economic performance in China: A bootstrapping approach in global data envelopment analysis. J Clean Prod 173:100-111. https://doi.org/10.1016/j.jclepro.2016.07.166

Yu Y, Liu B (2010) An empirical analysis on technological progress and its influencing factors in regional logistics industry. Shanghai Journal of Economics 10:3-12. https://doi.org/10.19626/j.cnki.cn31$1163 /$ f.2010.10.002

Yu Y, Huang J, Zhang N (2018) Industrial eco-efficiency, regional disparity, and spatial convergence of China's regions. J Clean Prod 204:872-887. https://doi.org/10.1016/j.jclepro.2018.09.054

Zaman K, Shamsuddin S (2017) Green logistics and national scale economic indicators: Evidence from a panel of selected European countries. J Clean Prod 143:51-63. https://doi.org/10.1016/j.jclepro.2016.12.150

Zhang L, Li D, Li A (2015) Dynamic changes in total factor energy efficiency and regional disparity in the logistics sector in China. Resour Sci 37:754-763.

Zhao PJ, Zeng LE, Lu HY, Zhou Y, Hu HY, Wei XY (2020) Green economic efficiency and its influencing factors in China from 2008 to 2017: Based on the super-SBM model with undesirable outputs and spatial Dubin model. Sci Total Environ 741:140026-140043. https://doi.org/10.1016/j.scitotenv.2020.140026

Zhou C, Shi C, Wang S, Zhang G (2018) Estimation of eco-efficiency and its influencing factors in Guangdong province based on Super-SBM and panel regression models. Ecol Indic 86:67-80. https://doi.org/10.1016/j.ecolind.2017.12.011

Zhou Y, Zhang M, Yang J (2015) A study on the eco-efficiency of logistics industry in provincial domain based on SE-DEA method. J Beijing Jiaotong Univ (Soc Sci) 14:99-106. https://doi.org/10.16797/j.cnki.11-5224/c.2015.04.013

Zhou Y, Kong Y, Zhang T (2020) The spatial and temporal evolution of provincial eco-efficiency in China based on SBM modified three-stage data envelopment analysis. Environ Sci Pollut Res Int 27:85578569. https://doi.org/10.1007/s11356-019-07515-7

Zhu F, Wu X, Gao Y (2020) Decomposition analysis of decoupling freight transport from economic 
growth in China. Transp Res Part D: Transp Environ 78:102201-102213. https://doi.org/10.1016/j.trd.2019.12.003

Zhu Q, Geng Y, Sarkis J, Lai K-h (2011) Evaluating green supply chain management among Chinese manufacturers from the ecological modernization perspective. Transp Res Part E: Log Transp Rev 47:808-821. https://doi.org/10.1016/j.tre.2010.09.013 


\section{Supplementary Files}

This is a list of supplementary files associated with this preprint. Click to download.

- allrelevanteditablesourcefilesfigures.rar 